\title{
Distribution of Vascular Plant Communities in Slovenian Watercourses
}

\author{
Igor Zelnik *(1), Urška Kuhar, Matej Holcar, Mateja Germ and Alenka Gaberščik
}

Citation: Zelnik, I.; Kuhar, U.; Holcar, M.; Germ, M.; Gaberščik, A. Distribution of Vascular Plant Communities in Slovenian Watercourses. Water 2021, 13, 1071. https://doi.org/10.3390/w13081071

Academic Editor: Massimo Zacchini

Received: 9 March 2021

Accepted: 10 April 2021

Published: 13 April 2021

Publisher's Note: MDPI stays neutral with regard to jurisdictional claims in published maps and institutional affiliations.

Copyright: (c) 2021 by the authors. Licensee MDPI, Basel, Switzerland. This article is an open access article distributed under the terms and conditions of the Creative Commons Attribution (CC BY) license (https:// creativecommons.org/licenses/by/ $4.0 /)$.
Department of Biology, Biotechnical Faculty, University of Ljubljana, Jamnikarjeva 101, 1000 Ljubljana, Slovenia; ursska.kuhar@gmail.com (U.K.); matej.holcar@bf.uni-lj.si (M.H.); mateja.germ@bf.uni-lj.si (M.G.); alenka.gaberscik@bf.uni-lj.si (A.G.)

* Correspondence: igor.zelnik@bf.uni-lj.si

\begin{abstract}
Rivers and streams are heterogenous ecosystems that host a great number of vascular plant communities. The territory of Slovenia is highly diverse regarding geomorphologic, geologic, climatic, and edaphic conditions. We presumed that environmental variability will also affect the distribution of hygrophilous vascular plants in running waters and consequently the structure of plant communities they form. We analyzed macrophyte, spatial, and environmental parameters in 906 stretches of the watercourses occurring in the Dinaric, Pannonian, and Po lowland hydro-ecoregions. We determined 87 vascular plant taxa. The most abundant were Myriophyllum spicatum, Phalaris arundinacea, and Potamogeton nodosus. Submerged macrophytes presented about one third of total species abundance, while amphiphytes were somewhat less abundant. Canonical correspondence analysis (CCA) revealed that distance from the source explained 15.1\% of the growth form type variability, and current velocity and latitude explained $4.1 \%$ each. With the assessed parameters, we explained $31.6 \%$ of the variability. When CCA was run with taxa, only $20.9 \%$ of their variability was explained with statistically significant parameters. We distinguished 25 different plant associations belonging to five classes and nine alliances. The majority of defined plant communities were distributed in different watercourses belonging to different hydro-ecoregions. Only seven communities had a narrower distribution range, three of them on karst poljes. Among them, the new association Mentho aquaticae-Oenanthetum fistulosae from the river Mali Obrh on the Loško polje was described in this contribution.
\end{abstract}

Keywords: macrophytes; growth forms; plant communities; distribution; rivers; streams; Slovenia

\section{Introduction}

Rivers, as well as streams, exhibit high spatial and temporal heterogeneity, which is a consequence of their interactions across four dimensions: longitudinal, lateral and vertical, and temporal [1]. These interactions enable the exchange of energy, matter, and organisms [2]. The strength of spatial interactions is changing along the river flow and due to human influences on water flow, riverbed shape, and its connection to the floodplains in catchments [3]. These interactions may result in different disturbances, such as increased current velocity, erosion, fluctuations of water level, siltation and sedimentation, and other pressures like changes in water quality (i.e., $\mathrm{pH}$, temperature and concentrations of dissolved oxygen, nutrients, and toxic metals) [4,5]. Thus, rivers present a highly unpredictable habitat for organisms. The extent of the pressures exerted on the rivers depends on the properties of the catchment, namely slope, geology, land cover parameters, and human impact on river morphology. All these parameters may significantly alter riverine communities, including macrophytes [6-8].

Macrophyte communities respond to changes in their habitats and reflect the quality of the wider environment [9-13]. However, the relationship is also reversed, since longitudinal transport of dissolved nutrients and particulate matter in rivers depends on the type of macrophyte communities and their retention potential [14]. Different macrophyte 
communities vary significantly in their productivity and respond differently to nutrient concentrations [15]. Therefore, the relationships between nutrient level and community structure also vary significantly [16]. In addition to nutrients, current velocity is also considered as an important factor shaping macrophyte communities [17,18], affecting their distribution, species composition, biomass, and macrophyte metabolism $[19,20]$. In many cases, current velocity determines whether plants will successfully colonize and establish stable communities in a specific habitat [21-23]. Additionally, current velocity also affects plant communities indirectly, through the effects on the substrate and on erosion processes. Macrophyte communities are also the result of species competition, especially in terms of competition for light, nutrients, and space [24]. Competitive potential of macrophytes depends on their traits regarding growth dynamics, carbon assimilation, energy harvesting, and nutrient uptake [25]. Nutrient uptake by macrophytes in rivers is variable due to seasonality and their growth dynamics [26]. All these parameters may exert negative effects on macrophyte communities. In the case of European lowland watercourses, a decline in macrophyte species diversity and unification of communities was detected in recent decades. In many systems, fast-growing species with a wide ecological range are favored, which prevents the development of other more demanding species [27,28].

Globally, many vascular macrophyte species have broad distribution ranges, however, about $39 \%$ of the ca. 412 genera containing aquatic vascular macrophytes are endemic to a single biogeographic region [29]. In the case of 345 sites in central North America, temperature did not turn out to be an important factor affecting macrophyte distribution, although it may exert an indirect effect on waterbody properties [30]. For fluvial lakes, it was shown that the landscape morphometric parameters explained a great share of spatial distribution of submerged macrophyte communities [31], while in the case of eastern Pyrenean lakes water chemistry, altitude, vegetation cover of the catchment, and nutrient availability were the major environmental factors affecting macrophyte distribution [32]. Linear models indicated that richness of emergent species in ponds was negatively affected by total phosphorous, while the land cover factors affected submerged species richness [33].

The Slovenian territory is geographically highly diverse regarding geomorphologic, geologic, climatic, and edaphic conditions. Slovenia is also situated on the junction of four biogeographic regions, namely the Alpine, Dinaric, Pannonian, and (sub)Mediterranean regions [34-36]. The high environmental diversity of Slovenia results in high biodiversity [37]. For the purpose of aquatic ecosystem management, Slovenian territory was re-delineated to the Alpine, Dinaric, Pannonian, and Po regions [38]. Many watercourses, especially in the Dinaric region, are marked by an intermittent water regime, which generates physical disturbances due to extreme water level fluctuations and affects conditions in rivers, namely nutrient availability and occasionally even intermittence [39]. Studies of many authors $[6,40,41]$ have revealed positive relationships between moderate water level changes and species diversity, as well as productivity.

Vegetation of aquatic ecosystems and distribution of aquatic plant communities have been studied with significantly lower intensity compared to terrestrial plant communities [42,43]. The result is a lack of knowledge in this research area, at least in some parts of Europe [44], which should be elaborated, especially due to high threats to these habitats. The above-mentioned facts are even more true in the case of running waters [42]. With this contribution, we would like to fill this gap for the part of central Europe, since our research area covers three hydro-ecoregions, namely the Po lowland, the Dinaric, and the Pannonian lowland, and represents an area reaching beyond the borders of the territory of Slovenia, which is also evident from Figure 1. 


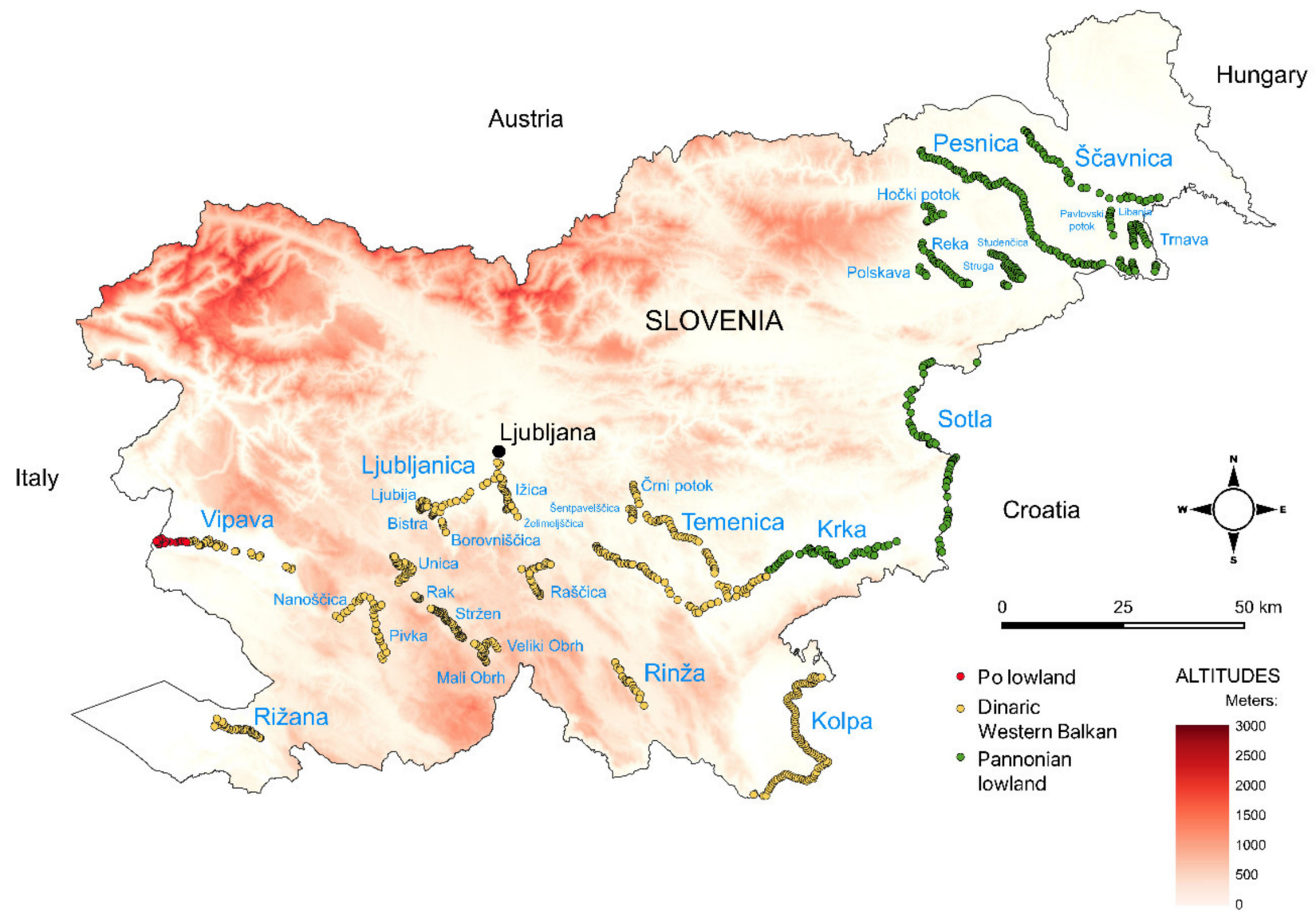

Figure 1. Map of Slovenia showing the distribution of surveyed sites. Circles of different colors indicate different hydroecoregions. The font size of the name roughly indicates the size of the specific watercourse.

In this study, we investigated 34 Slovenian watercourses belonging to the hydroecoregions the Po lowland, Dinarides, and the Pannonian lowland, in order to examine growth forms of macrophyte species and macrophyte communities in these watercourses, and to point out the potential regionality of these communities. We also expected that environmental variability would affect number of taxa, their abundance, and the occurrence of different growth forms.

\section{Materials and Methods}

\subsection{Study Area}

The geologic and climatic conditions of Slovenia are very diverse. Sedimentary rocks, of which limestone and dolomite predominate, cover $65.1 \%$ of the territory. Loose sediments (gravel, sand) are found in tectonic depressions and river valleys and contribute an additional $29.2 \%$. Metamorphic rocks are mostly concentrated in northeast Slovenia accounting for $4.1 \%$, while igneous rocks cover only $1.6 \%$ of the surface and are found along the Periadriatic fault and in the Pohorje Mountains [45]. Three types of climate occur in Slovenia, namely temperate humid climate with hot summers, temperate continental climate, and mountain climate, with the highest precipitation in the Julian Alps (in the northwest), which is at least three times the precipitation of the Pannonian northeastern Slovenia [46]. Slovenia is also the junction of four biogeographic regions, namely the Alpine, Dinaric, Pannonian, and (sub)Mediterranean regions [34-36].

For the purpose of this study, we investigated watercourses that belong to three hydroecoregions, namely Dinaric, Po lowland, and Pannonian lowland. The watercourses from the Alpine region were excluded, as vascular plants are scarce in this region. The majority of the Slovenian territory (about $16.500 \mathrm{~km}^{2}$ ) is drained into the Black Sea, while $3.750 \mathrm{~km}^{2}$ is 
drained into the Adriatic Sea [47]. Only two among the studied rivers (Vipava and Rižana) belong to the Adriatic catchment area. Altogether, we examined 1141 reaches of which 535 reaches belong to the hydro-ecoregion Dinarides, 352 reaches belong to the hydroecoregion Pannonian lowland, while only 19 belong to the hydro-ecoregion Po lowland. The watercourses Vipava (50), Rižana (32), Kolpa (96), Krka (108), Sotla (54), Temenica (51), Mali Obrh (12), Veliki Obrh (15), Stržen (42), Rak (8), Nanoščica (12), Pivka (18), Unica (29), Ljubljanica (22), Ižica (23), Ljubija (10), Bistra (7), Borovniščica (7), Želimelǰ̌čica (3), Rinža (18), Rašica (14), Polskava (12), Črni potok (13), Šentpavelščica (9), Hočki potok (14), Reka (21), Studenčnica (11), Struga (22), Pesnica (85), Ščavnica (39), Pavlovski potok (16), Libanja (17), and Trnava (16) were examined (Figure 1).

\subsection{Macrophyte Data Set}

Surveys were carried out in the years 2002-2006 along the entire stream courses. New sampling stretches were determined according to major changes in habitat characteristics and macrophyte distribution; $100 \mathrm{~m}$ stretches were determined on ca. $500 \mathrm{~m}$ intervals. A similar approach, but with $1000 \mathrm{~m}$ stretches, was used in the macrophyte survey of the Danube River [48]. Macrophyte surveys were performed from the bank of the stream, by wading in the stream or from a boat, using a rake with hooks. We recorded submerged, floating, and emergent vascular plants, bryophytes, charophytes, and filamentous algae. Macrophyte species abundance was estimated as a relative plant biomass using a five-degree scale, namely 1-very rare, 2-rare, 3-commonly present, 4-frequent, and 5 -predominant, as proposed by Kohler and Janauer [49]. These values were transformed by the function $x^{3}$, as suggested by Schneider and Melzer [50]. The plants that were sampled in the vegetative phenological phase, which prevented identification to the species level, were only recorded on the genus level. We differentiated the following growth forms: pleustophytes (pl-free-floating on or below the water surface), submerged anchored species (sa-rooted in the sediment), floating-leaved species (fl-rooted in the sediment, forming exclusively or additionally leaves floating on the water surface), amphiphytes (am-having the ability to produce terrestrial and aquatic growth forms, or aquatic and aerial leaves), and helophytes (he-anchored in the water-saturated sediment, with plant assimilation areas permanently in the air) [51]. Stretches that were colonized only by bryophytes and stoneworts, and stretches with very low abundance of vascular species, namely less than 4 vascular plant species with lowest abundance values, were excluded from the analyses. A set of 906 sampled stretches was analyzed. Species names followed the nomenclature of Flora Europaea [52]. For the purpose of community analyses, the ordinal values of the Kohler-scale were transformed into quantitative values ("quantities") [53]. We equalized the transformed values as percentage cover-abundance values according to Braun-Blanquet [54], as previously tested and used by other authors [55,56]. We also used these "adjusted" values to examine if the clusters obtained by cluster analysis meet the definitions of specific associations, which are mostly defined by presence and/or abundance of diagnostic species. These values for dominant species are presented in Table A1 in Appendix A.

\subsection{Environment Assessment}

The assessment of environmental conditions in the selected watercourses was performed in the same stretches as the survey of macrophytes. We applied a modified Riparian, Channel, and Environmental (RCE) Inventory, proposed by Petersen [9] that comprised 11 parameters, each describing four levels of environmental gradient. The parameters include land-use type beyond the riparian zone, characteristics of the riparian zone (width, completeness, and vegetation type), and morphology of the stream channel (bank structure and undercutting, occurrence of retention structures, sediment accumulation, type of stream bottom and detritus, and dynamics of the flow, i.e., occurrence of riffles, pools, and meanders) [7,57]. Each parameter includes four categories comprising quality gradient, coded numerically from 1 to $4 ; 1$ represented good, close to natural condition, while quality 
gradient values from 2 to 4 indicated worsening of environmental conditions or differences either due to regional characteristics or due to the longitudinal character of the river. We also assessed current velocity according to Janauer et al. [58] using a 4-level scale (1-no visible current, 2-slow, $>0$ to $30 \mathrm{~cm} \mathrm{~s}^{-1}$, 3-medium, 35 to $65 \mathrm{~cm} \mathrm{~s}^{-1}$, and 4-fast current, $>70 \mathrm{~cm} \mathrm{~s}^{-1}$ ).

Maps were made using QGIS version 3.16 [59].

\subsection{Data Analyses and Classification of Aquatic Plant Communities}

Diversity was measured as the number of species and the Shannon-Wiener diversity index $\left(\mathrm{H}^{\prime}\right)$, which was calculated based on mean cover values with PAST, version 2.17c [60]. Correlations between diversity, abundance of macrophyte communities, and environmental parameters were calculated with Spearman correlation on ranks using PAST, version 2.17c [60]. Similarity of macrophyte communities between the stretches was also calculated with the aforementioned program. Ward's method was used as linkage method and Euclidean distance was used as similarity index [61], which provided clustering with lowest levels of chaining [62]. This enabled the comparison of similarity among the assemblages from different locations and their classification into plant communities. We used the approach based on the dominant species, which is also diagnostic for specific associations. This approach is frequently used for aquatic vegetation [63]. Dominancebased classification for species-poor plant communities is most similar to the approaches in traditional phytosociology [64].

Classification of plant communities was based on the definitions proposed by Šumberová and co-workers [65-68], Zaliberová and Škodová [69], and Landucci et al. [70]. Nomenclature of higher syntaxa (classes, alliances) followed Mucina et al. [71], while nomenclature of associations was in accordance with Šumberová and co-workers [65-68], Landucci et al. [70], and Zaliberová and Škodová [69].

\subsection{The Influence of Environmental Factors on Macrophyte Community Composition}

Firstly, detrended correspondence analysis (DCA) was performed, which helped us to evaluate whether the gradients in the matrix of macrophyte species data were linear or unimodal, and choose the appropriate direct gradient analysis for further analyses. If the eigenvalue for the first axis was at least 0.4 and gradient length exceeded 3 standard deviations, respectively, as suggested by ter Braak and Verdonschot [72], canonical correspondence analysis (CCA) was performed, while in other cases redundancy analysis would have been conducted (RDA). Species abundance values were $\log (x+1)$-transformed. Results of these analyses enabled the assessment of the relationships between environmental parameters and distribution and abundance of macrophytes and their growth forms. In addition to 12 of the above-mentioned environmental parameters, we also tested the relationships between macrophytes and presence and abundance of filamentous algae, as well as selected geographical parameters, i.e., longitude and latitude, distance from the source, slope, and altitude.

We used forward selection, where 999 permutations were performed in every round to rank the relative importance of explanatory variables and to avoid co-linearity [73]. Only the parameters with significance $p<0.05$ (or $p \leq 0.001$ in the case of growth forms) were considered for further analyses. All analyses were performed using CANOCO for Windows 4.5 program package [74,75].

\section{Results}

\subsection{Macrophyte Taxa and Their Growth Forms}

In the surveyed stretches of selected watercourses, we determined a total of 87 vascular plant taxa that belonged to different growth forms. When comparing total abundance of vascular macrophytes in the surveyed watercourses, submerged macrophytes prevailed with $36.0 \%$, followed by amphiphytes (29.9\%). A somewhat lower share $(18.2 \%)$ was attributed to helophytes and floating-leaved plants (12.9\%), while pleustophytes, namely all 
the free-floating vascular plant taxa, had the lowest share (3.1\%). The most abundant species was Myriophyllum spicatum (12.0\%), followed by Phalaris arundinacea (6.7\%), and Potamogeton nodosus $(6.6 \%)$, while the abundance of the species Berula erecta, P. perfoliatus, alien species Elodea canadensis, P. crispus, P. pectinatus, Nuphar luteum, P. natans, and Schoenoplectus lacustris contributed 3-4\% each. Another 76 species altogether contributed about a half (51.1\%) to the total relative abundance. Relative abundances of macrophyte species in stretches of the surveyed watercourses are presented in Figure 2.

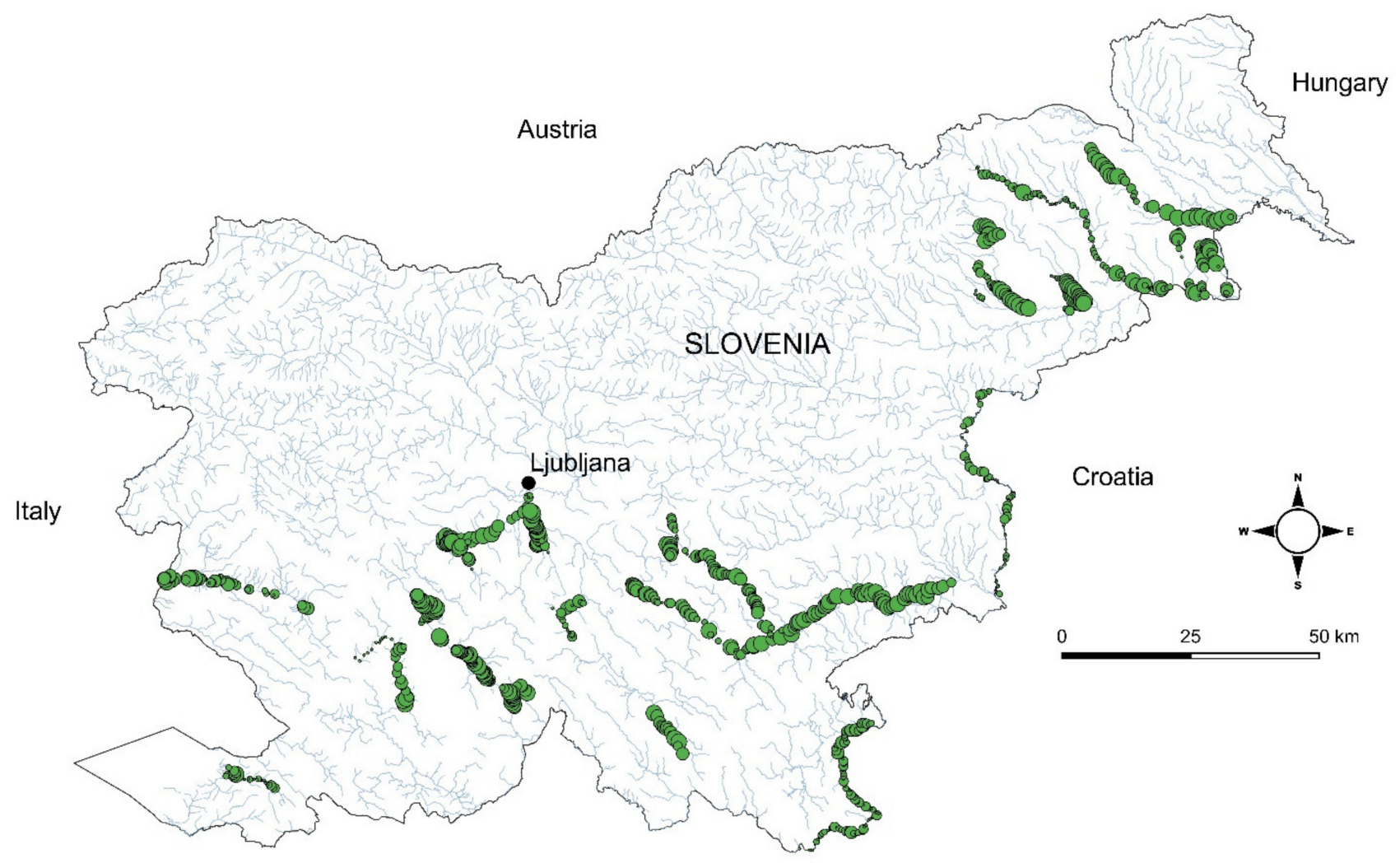

Figure 2. Relative abundance of macrophyte species presented as size of the circles in the stretches of the surveyed watercourses.

Correlation analyses revealed positive relationships between species diversity and retention structures, sediment, and detritus deposition, while there were negative relationships between filamentous algae abundance and current velocity and slope. In addition, a negative relationship was also obtained between species diversity and distance from the source, while a positive relationship was found between species diversity and altitude (Table 1). 
Table 1. Spearman correlation coefficients between diversity, abundance, and assessed environmental variables. S-W-Shannon-Wiener diversity index; ${ }^{* * *}$ —very highly significant $(p<0.001)$, ** highly significant $(p<0.01), *$ - significant $(p<0.05)$.

\begin{tabular}{cccc}
\hline Variable & No. of Taxa & S-W & Abundance \\
\hline Distance from the source & $-0.314^{* * *}$ & $-0.304^{* * *}$ & $-0.215^{* * *}$ \\
Altitude & $0.383^{* * *}$ & $0.363^{* * *}$ & $0.175^{* * *}$ \\
Slope & $-0.141^{* * *}$ & $-0.132^{* * * *}$ & $-0.167^{* * *}$ \\
Land use & $0.084^{* *}$ & $0.097^{* *}$ & $0.115^{* * *}$ \\
Width of riparian zone & $\mathrm{ns}$ & $\mathrm{ns}$ & $\mathrm{ns}$ \\
Completeness of riparian zone & $0.123^{* * *}$ & $0.131^{* * *}$ & $0.133^{* * *}$ \\
Vegetation of riparian zone & $0.072^{*}$ & $0.078^{*}$ & $0.131^{* * *}$ \\
Retention structures & $0.188^{* * *}$ & $0.169^{* * *}$ & $0.104^{* *}$ \\
Sediment deposition & $0.196^{* * *}$ & $0.206^{* * *}$ & $0.184^{* * *}$ \\
Riverbed bottom & $0.207^{* * *}$ & $0.180^{* * *}$ & $0.202^{* * *}$ \\
Flow dynamics & $0.120^{* * *}$ & $0.129^{* * *}$ & $0.121^{* * *}$ \\
Presence of detritus & $0.216^{* * *}$ & $0.189^{* * *}$ & $0.192^{* * *}$ \\
Current velocity & $-0.365^{* * *}$ & $-0.322^{* * *}$ & $-0.386^{* * *}$ \\
Presence of filamentous algae & $-0.205^{* * *}$ & $-0.191^{* * *}$ & $\mathrm{~ns}$ \\
\hline
\end{tabular}

\subsection{The Relationships between Growth Forms and Environmental Factors}

The CCA ordination plot (Figure 3) showing the relationships between the abundance of growth forms and significant environmental parameters in different stretches is presented in Figure 3. This analysis revealed that distance from the source explained $15.1 \%$ of the growth form type variability, current velocity and latitude explained $4.1 \%$ each, the presence of filamentous algae $2.7 \%$, altitude and river bottom $1.4 \%$ each, and sediment deposition explained less than $0.5 \%$. All these parameters were very highly significant $(p \leq 0.001)$. Altogether, with the environmental parameters, we explained $31.6 \%$ of the variability of presence and abundance of plant growth form types. Submerged plants and floating-leaved plants were related to distance from the source, pleustophytes to current velocity, while amphiphytes and helophytes were related to slope and river bottom.

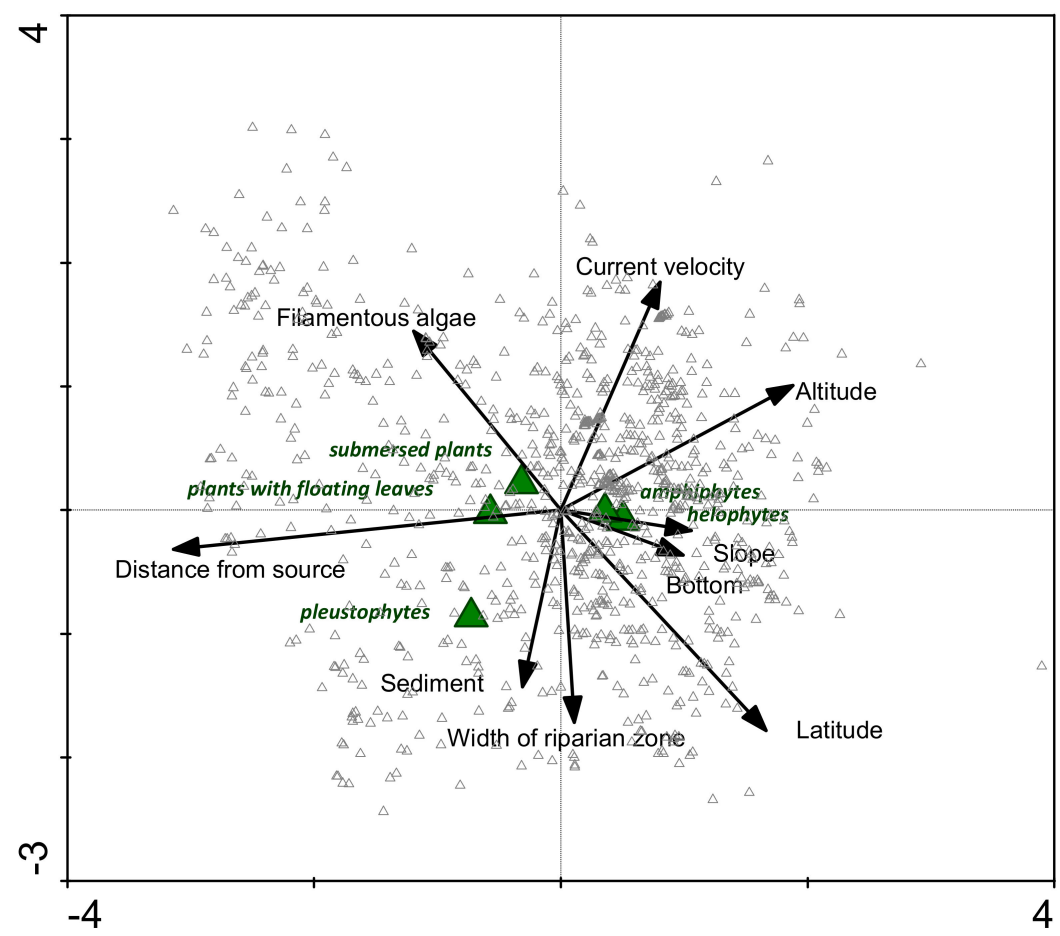

Figure 3. CCA (canonical correspondence analysis) plot showing the relationships between the abundance of different growth forms and significant environmental parameters detected in different stretches of the examined rivers. 


\subsection{Relationships between Species and Environmental Factors}

CCA revealed that all the tested environmental parameters significantly affected the variability of species presence and abundance $(p \leq 0.001)$, however, the share of explained variance was rather low, altogether $20.9 \%$ (Figure 4). Geographical parameters were revealed to be the most important. Distance from the source explained $4.9 \%$, altitude $3.8 \%$, longitude $2.4 \%$, latitude $1.7 \%$, current velocity $1.1 \%$, and the presence of filamentous algae and width of riparian zone $0.95 \%$ of the variability each. The remaining parameters explained altogether an additional $5.5 \%$ of the variability of species presence and abundance.

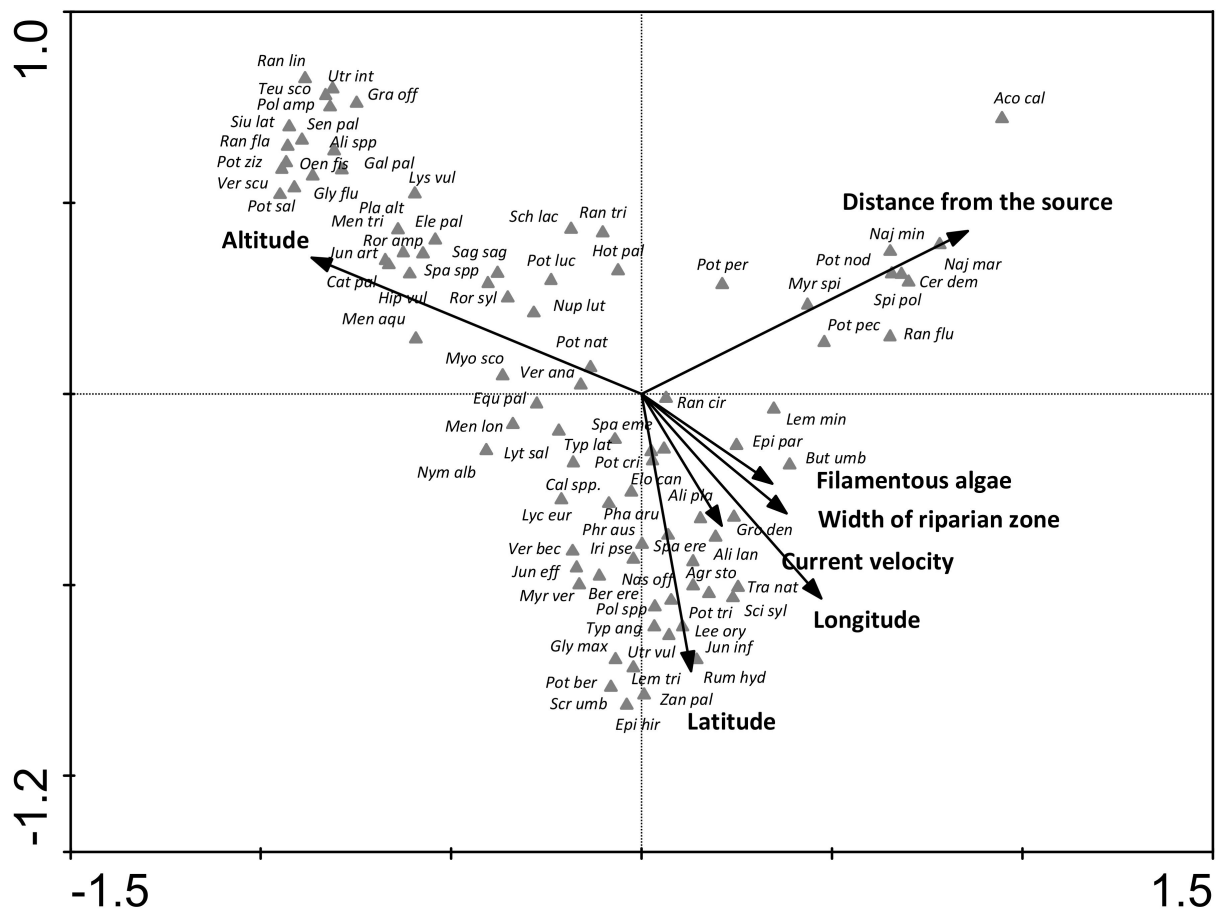

Figure 4. CCA plot showing the relationships between species presence and abundance, and significant environmental parameters detected in different stretches of the examined rivers. Only the parameters explaining at least $0.95 \%$ of the variability of species presence and abundance are presented. Abbreviated species names: Acorus calamus (Aco cal), Agrostis stolonifera agg. (Agr sto), Alisma lanceolatum (Ali lan), Alisma plantago-aquatica (Ali pla), Alisma spp. (Ali spp), Berula erecta (Ber ere), Butomus umbellatus (But umb), Callitriche spp. (Cal spp.), Caltha palustris (Cat pal), Ceratophyllum demersum (Cer dem), Eleocharis palustris (Ele pal), Elodea canadensis (Elo can), Epilobium hirsutum (Epi hir), Epilobium parviflorum (Epi par), Equisetum palustris (Equ pal), Galium palustre (Gal pal), Glyceria fluitans (Gly flu), Glyceria maxima (Gly max), Gratiola officinalis (Gra off), Groenlandia densa (Gro den), Hippuris vulgaris (Hip vul), Hottonia palustris (Hot pal), Iris pseudacorus (Iri pse), Juncus articulatus (Jun art), Juncus effusus (Jun eff), Juncus inflexus (Jun inf), Leersia oryzoides (Lee ory), Lemna minor (Lem min), Lemna trisulca (Lem tri), Lycopus europaeus (Lyc eur), Lysimachia vulgaris (Lys vul), Lythrum salicaria (Lyt sal), Mentha aquatica (Men aqu), Mentha longifolia (Men lon), Menyanthes trifoliata (Men tri), Myosotis scorpioides agg. (Myo sco), Myriophyllum spicatum (Myr spi), Myriophyllum verticillatum (Myr ver), Najas marina (Naj mar), Najas minor (Naj min), Nasturtium officinale (Nas off), Nuphar luteum (Nup lut), Nymphaea alba (Nym alb), Oenanthe fistulosa (Oen fis), Phalaris arundinacea (Pha aru), Phragmites australis (Phr aus), Plantago altissima (Pla alt), Polygonum amphibium (Pol amp), Polygonum spp. (Pol spp), Potamogeton berchtoldii (Pot ber), Potamogeton crispus (Pot cri), Potamogeton lucens (Pot luc), Potamogeton natans (Pot nat), Potamogeton nodosus (Pot nod), Potamogeton pectinatus (Pot pec), Potamogeton perfoliatus (Pot per), Potamogeton salicifolius (Pot sal), Potamogeton trichoplyllus (Pot tri), Potamogeton x zizii (Pot ziz), Ranunculus circinatus (Ran cir), Ranunculus flammula (Ran fla), Ranunculus fluitans (Ran $f l u)$, Ranunculus lingua (Ran lin), Ranunculus trichophyllus (Ran tri), Rorippa sylvatica (Ror amp), Rorippa amphibia (Ror syl), Rumex hydrolapathum (Rum hyd), Sagittaria sagittifolia (Sag sag), Schoenoplectus lacustris (Sch lac), Scirpus sylvaticus (Sci syl), Scrophularia umbrosa (Scr umb), Senecio paludosus (Sen pal), Sium latifolium (Siu lat), Sparganium emersum (Spa eme), Sparganium erectum agg. (Spa ere), Sparganium spp. (Spa spp.), Spirodela polyrhiza (Spi pol), Teucrium scordium (Teu sco), Trapa natans (Tra nat), Typha angustifolia (Typ ang), Typha latifolia (Typ lat), Utricularia intermedia (Utr int), Utricularia vulgaris (Utr vul), Veronica anagallis-aquatica (Ver ana), Veronica beccabunga (Ver bec), Veronica scutellata (Ver scu), Zannichellia palustris (Zan pal). 


\subsection{Macrophyte Communities}

The similarity of macrophyte communities is presented in Figure 5, showing clustering of stretches. We distinguished 34 different clusters that were the basis for the definition of 25 associations belonging to five classes and nine alliances. Synoptic table shows the relative importance of different taxa (dominant and subdominant), expressed as average values of cover-abundance (Table A1), while plant communities based on these clusters are presented in Table 2. Overall, we determined 25 dominant taxa and 44 subdominant taxa.

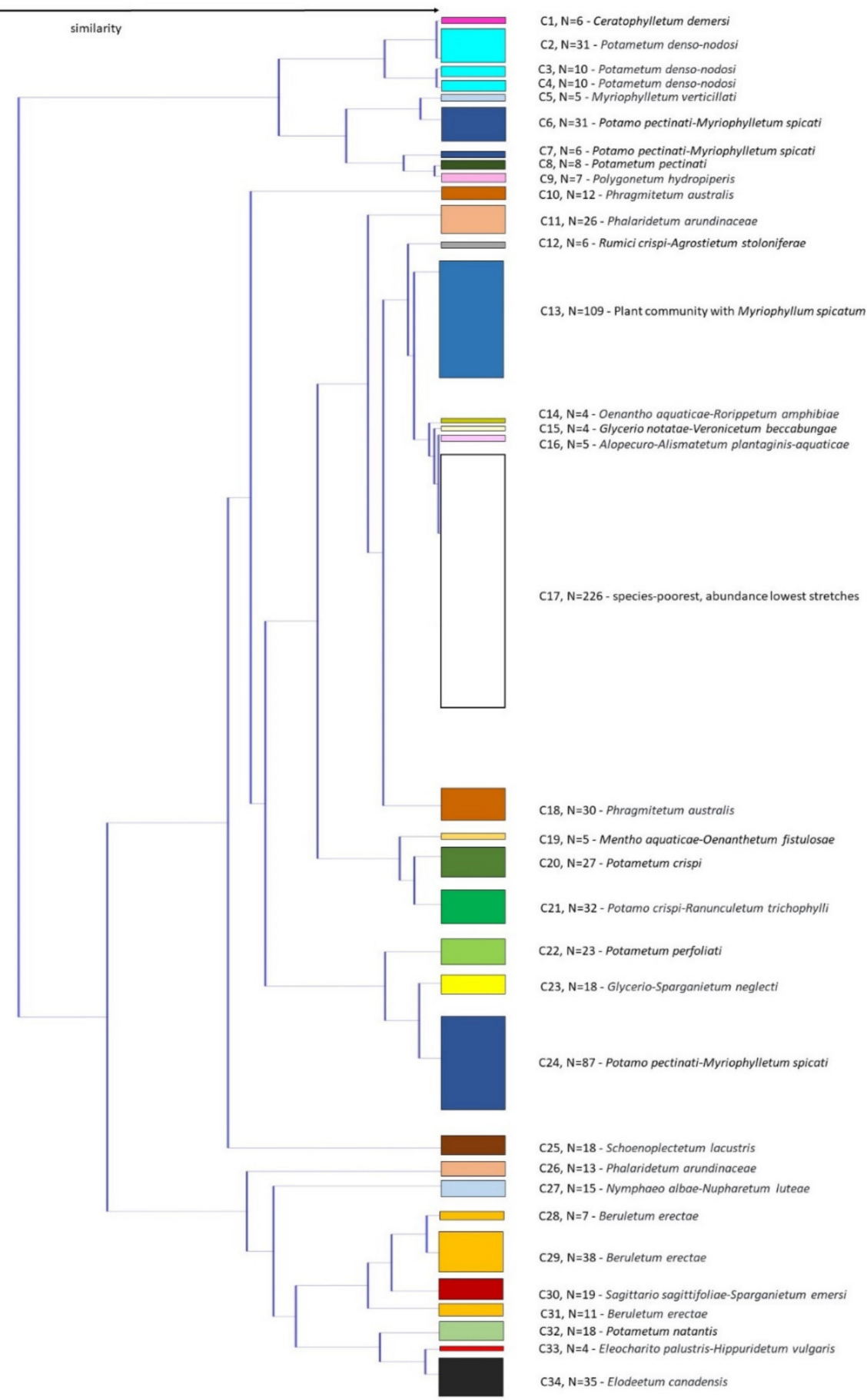

Figure 5. Similarity of the macrophyte stands, recorded in the studied watercourses using Ward's linkage method and Euclidean distance similarity index. 
Table 2. Clusters classified into plant communities, their formal definitions as well as dominant and subdominant species.

\begin{tabular}{|c|c|c|c|c|}
\hline \multirow[b]{2}{*}{$\begin{array}{l}\text { Cluster } \\
\text { Number }\end{array}$} & \multirow[b]{2}{*}{$\mathbf{N}$} & \multirow[b]{2}{*}{ Plant Communities } & \multicolumn{2}{|c|}{ Formal Definition } \\
\hline & & & $\begin{array}{c}\text { Coverage }(\%) \text { of Dominant Taxa; } \\
\text { Subdominant }\end{array}$ & NOT \\
\hline 1 & 6 & Ceratophylletum demersi Corillion 1957 & Ceratophyllum demersum $>50 \%$ & $\begin{array}{c}\text { Potamogeton crispus }>25 \% \\
\text { Potamogeton natans }>25 \% \\
\text { Potamogeton nodosus }>25 \% \\
\text { Ceratophyllum submersum }>25 \% \\
\text { Nuphar luteum }>25 \% \\
\text { Phragmites australis }>25 \% \\
\text { Sagittaria sagittifolia }>25 \% \\
\text { Sparganium erectum }>25 \%\end{array}$ \\
\hline 2 & 31 & Potametum denso-nodosi de Bolós 1957 & $\begin{array}{l}\text { Potamogeton nodosus }>25 \% \\
\text { codominant } \text { C. demersum }\end{array}$ & \\
\hline 3 & 10 & Potametum denso-nodosi de Bolós 1957 & $\begin{array}{l}\text { Potamogeton nodosus }>25 \% \\
\text { subdominant } C \text {. demersum }\end{array}$ & $\begin{array}{l}\text { Sagittaria sagittifolia }>25 \% \\
\text { Sparganium emersum }>25 \%\end{array}$ \\
\hline 4 & 10 & Potametum denso-nodosi de Bolós 1957 & Potamogeton nodosus $>25 \%$ & \\
\hline 5 & 5 & $\begin{array}{l}\text { Myriophylletum verticillati Gaudet ex } \\
\text { Šumberová in Chytrý } 2011\end{array}$ & Myriophyllum verticillatum $>25 \%$ & \\
\hline 6 & 31 & $\begin{array}{c}\text { Potamo pectinati-Myriophylletum spicati } \\
\text { Rivas Goday } 1964\end{array}$ & Myriophyllum spicatum $>50 \%$ & $\begin{array}{c}\text { Butomus umbellatus }>25 \% \\
\text { Nuphar luteum }>25 \% \\
\text { Sparganium emersum }>25 \%\end{array}$ \\
\hline 7 & 6 & $\begin{array}{c}\text { Potamo pectinati-Myriophylletum spicati } \\
\text { Rivas Goday } 1964\end{array}$ & Myriophyllum spicatum $>50 \%$ & Potamogeton pectinatus \\
\hline 8 & 8 & $\begin{array}{c}\text { Potametum pectinati Carstensen ex } \\
\text { Hilbig } 1971\end{array}$ & Potamogeton pectinatus $>50 \%$ & Zannichellia palustris $>5 \%$ \\
\hline 9 & 7 & Polygonetum hydropiperis Passarge 1965 & $\begin{array}{c}\text { Polygonum hydropiper } / \text { mite }>50 \% \\
\text { codom.: Myriophyllum spicatum, } \\
\text { Phalaris arundinacea }\end{array}$ & $\begin{array}{l}\text { Chenopodium glaucum } \\
\text { Ranunculus sceleratus } \\
\text { Urtica dioica }>25 \%\end{array}$ \\
\hline 10 & 12 & Phragmitetum australis Savič 1926 & Phragmites australis $>50 \%$ & \\
\hline 11 & 26 & Phalaridetum arundinaceae Libbert 1931 & $\begin{array}{c}\text { Phalaris arundinacea }>25 \% \text { AND } \\
\text { (groups Bidens frondosa/Cirsium } \\
\text { oleraceum/Urtica dioica) }\end{array}$ & \\
\hline 12 & 6 & $\begin{array}{c}\text { Rumici crispi-Agrostietum stoloniferae } \\
\text { Moor } 1958\end{array}$ & $\begin{array}{c}\text { Rorippa sylvestris AND Agrostis } \\
\text { stolonifera agg. }>25 \% \text { OR Bidens } \\
\text { tripartita }>50 \%\end{array}$ & \\
\hline
\end{tabular}

$13 \quad \begin{gathered}\text { Community with Myriophyllum } \\ \text { spicatum }\end{gathered}$ dominant Myriophyllum spicatum

low dominance (15\%)-Phalaris spicatum arundinacea, Potamogeton nodosus

Glyceria maxima cover $>25 \%$

Phalaris arundinacea $>25 \%$

$14 \quad$ Oenantho aquaticae-Rorippetum amphibiae Lohmeyer 1950
Rorippa amphibia $>25 \%$; Alisma plantago-aquatica
Phragmites australis $>25 \%$

Sagittaria sagittifolia $>25 \%$

Schoenoplectus lacustris $>25 \%$ Sparganium erectum $>25 \%$
$154 \quad$ Glycerio notatae-Veronicetum beccabungae Landucci et al. 2020

16

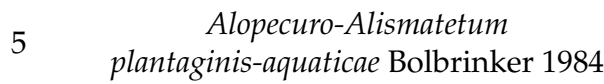

Alisma plantago-aquatica $>25 \%$
Alisma lanceolatum $>25 \%$

Glyceria maxima $>25 \%$

Sparganium emersum $>25 \%$ Sparganium erectum $>25 \%$ 
Table 2. Cont

\begin{tabular}{|c|c|c|c|c|}
\hline \multirow[b]{2}{*}{$\begin{array}{l}\text { Cluster } \\
\text { Number }\end{array}$} & \multirow[b]{2}{*}{$\mathbf{N}$} & \multirow[b]{2}{*}{ Plant Communities } & \multicolumn{2}{|c|}{ Formal Definition } \\
\hline & & & $\begin{array}{c}\text { Coverage }(\%) \text { of Dominant Taxa; } \\
\text { Subdominant }\end{array}$ & NOT \\
\hline 17 & 226 & $\begin{array}{l}\text { species-poorest. abundance lowest } \\
\text { stretches }\end{array}$ & $\begin{array}{l}\text { Phalaris arundinacea. Lytrum } \\
\text { salicaria, Myosotis scorpioides }\end{array}$ & \\
\hline 18 & 30 & Phragmitetum australis Savič 1926 & Phragmites australis & $\begin{array}{c}\text { low dominance }(22 \%) ; \text { Nuphar } \\
\text { luteum }\end{array}$ \\
\hline 19 & 5 & $\begin{array}{l}\text { Mentho aquaticae-Oenanthetum } \\
\text { fistulosae ass. nova }\end{array}$ & Oenanthe fistulosa $>50 \%$ & \\
\hline 20 & 27 & Potametum crispi von Soó 1927 & Potamogeton crispus $>25 \%$ & $\begin{array}{c}\text { Nuphar luteum }>25 \% \\
\text { Potamogeton natans }>25 \% \\
\text { Phragmites australis }>25 \%\end{array}$ \\
\hline 21 & 32 & $\begin{array}{l}\text { Potamo crispi-Ranunculetum } \\
\text { trichophylli Imchenetzky } 1926\end{array}$ & $\begin{array}{c}\text { Ranunculus trichophyllus }>25 \% \\
\text { Potamogeton crispus }\end{array}$ & $\begin{array}{c}\text { Glyceria notata }>25 \% \\
\text { Juncus articulatus }>25 \%\end{array}$ \\
\hline 22 & 23 & Potametum perfoliati Miljan 1933 & Potamogeton perfoliatus $>25 \%$ & - \\
\hline 23 & 18 & $\begin{array}{c}\text { Glycerio-Sparganietum neglecti Koch } \\
1926\end{array}$ & Sparganium erectum agg. $>25 \%$ & Typha latifolia $>25 \%$ \\
\hline 24 & 87 & $\begin{array}{c}\text { Potamo pectinati-Myriophylletum } \\
\text { spicati Rivas Goday } 1964\end{array}$ & dominant Myriophyllum spicatum & \\
\hline 25 & 18 & $\begin{array}{c}\text { Schoenoplectetum lacustris Chouard } \\
1924\end{array}$ & Schoenoplectus lacustris $>25 \%$ & - \\
\hline 26 & 13 & $\begin{array}{l}\text { Phalaridetum arundinaceae Libbert } \\
1931\end{array}$ & $\begin{array}{c}\text { Phalaris arundinacea }>25 \% \text { AND } \\
\text { (groups Bidens frondosa/Cirsium } \\
\text { oleraceum/Urtica dioica) }\end{array}$ & \\
\hline 27 & 15 & $\begin{array}{c}\text { Nymphaeo albae-Nupharetum luteae } \\
\text { Nowiński } 1927\end{array}$ & Nuphar luteum $>25 \%$ & $\begin{array}{l}\text { Nymphaea alba }>5 \% \\
\text { Typha latifolia }>25 \%\end{array}$ \\
\hline 28 & 7 & Beruletum erectae Roll 1938 & $\begin{array}{c}\text { Berula erecta }>5 \% \\
\text { co-dominant Callitriche spp. }\end{array}$ & $\begin{array}{l}\text { Potamogeton perfoliatus, } \\
\text { Sparganium emersum }\end{array}$ \\
\hline 29 & 38 & Beruletum erectae Roll 1938 & $\begin{array}{c}\text { Berula erecta }>5 \% \\
\text { subdom. Callitriche spp. }\end{array}$ & \\
\hline 30 & 19 & $\begin{array}{c}\text { Sagittario sagittifoliae-Sparganietum } \\
\text { emersi Tüxen } 1953\end{array}$ & $\begin{array}{c}\text { Sagittaria sagittifolia }>25 \% \text { OR } \\
\text { Sparganium emersum }>25 \%\end{array}$ & $\begin{array}{c}\text { Butomus umbellatus }>25 \% \\
\text { Glyceria maxima }>25 \% \\
\text { Potamogeton gramineus }>25 \% \\
\text { Rorippa amphibia cover }>25 \% \\
\text { Sparganium erectum }>25 \%\end{array}$ \\
\hline 31 & 11 & Beruletum erectae Roll 1938 & Berula erecta $>5 \%$ & \\
\hline 32 & 18 & Potametum natantis Hild 1959 & Potamogeton natans $>25 \%$ & $\begin{array}{c}\text { Callitriche palustris s. } 1 .>25 \% \\
\text { Eleocharis palustris }>25 \% \\
\text { Glyceria fluitans }>25 \% \\
\text { Hippuris vulgaris }>25 \% \\
\text { Nuphar luteum }>25 \% \\
\text { Phragmites australis }>25 \% \\
\text { Potamogeton nodosus }>25 \% \\
\text { Sparganium emersum }>25 \% \\
\text { Sparganium erectum }>25 \%\end{array}$ \\
\hline 33 & 4 & $\begin{array}{c}\text { Eleocharito palustris-Hippuridetum } \\
\text { vulgaris Passarge } 1964\end{array}$ & Hippuris vulgaris $>25 \%$ & - \\
\hline 34 & 35 & Elodeetum canadensis Nedelcu 1967 & Elodea canadensis $>50 \%$ & $\begin{array}{c}\text { Equisetum fluviatile }>25 \% \\
\text { Potamogeton natans }>25 \% \\
\text { Schoenoplectus lacustris }>25 \% \\
\text { Sparganium erectum }>25 \%\end{array}$ \\
\hline
\end{tabular}


The majority of the defined communities are distributed in various watercourses belonging to different hydro-ecoregions (Figures 1 and 6). However, 7 out of 25 communities had a narrower distribution range (Figure 6). Among these were the association Myriophylletum verticillati, found only in the river Struga (NE Slovenia), the associations Potamo crispi-Ranunculetum trichophylli and Schoenoplectetum lacustris, which were mostly limited to watercourses in karst poljes, the association Polygonetum hydropiperis that occurred only in 7 stretches in the lower part of the river Ščavnica (NE Slovenia), the association Eleocharito palustris-Hippuridetum vulgaris that was one of the rarest and occurred only in the river Ižica in central Slovenia, the association Glycerio notatae-Veronicetum beccabungae, which was recorded only in 4 stretches of the upper part of the river Temenica in central Slovenia, and the newly described association Mentho aquaticae-Oenanthetum fistulosae that was recorded only in 5 stretches of the river Mali Obrh on Loško polje, which is also a karstic polje.

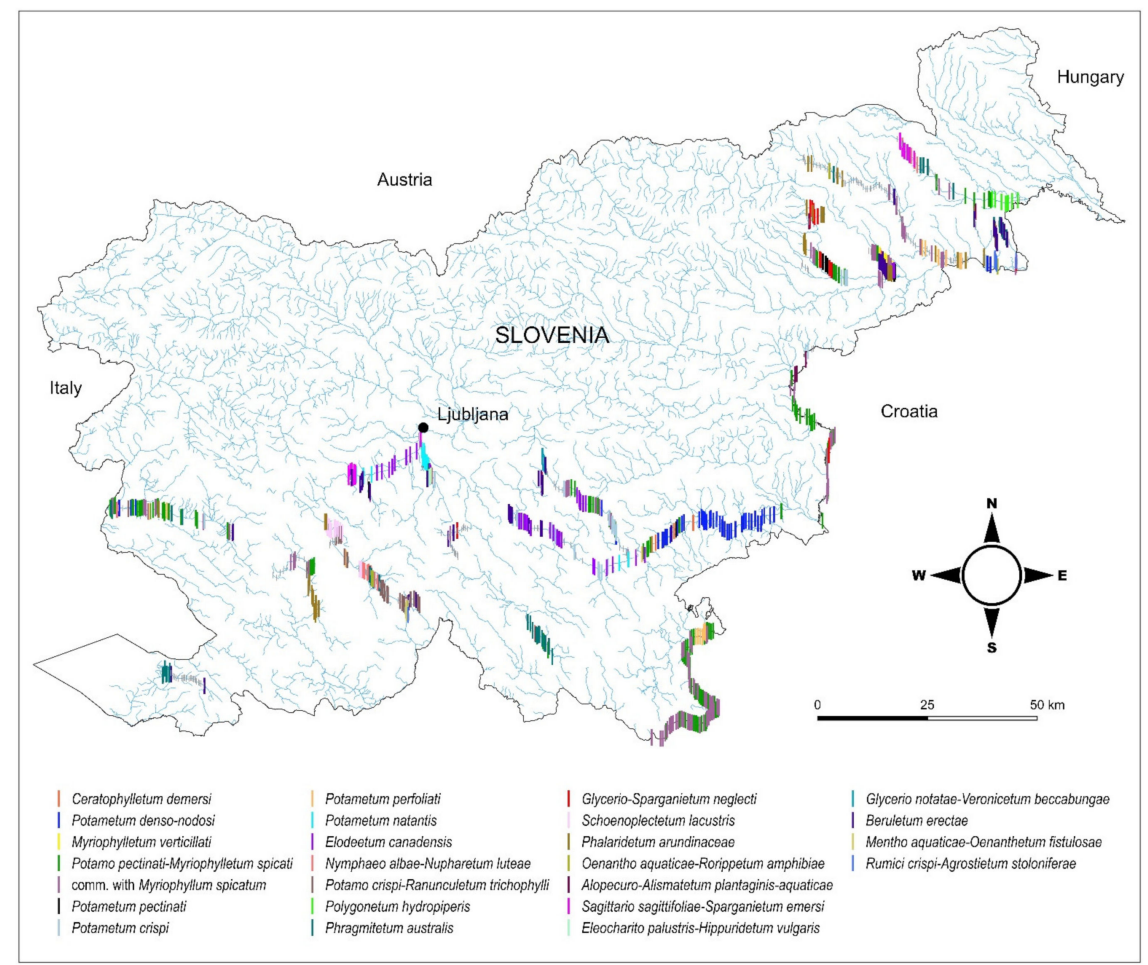

Figure 6. Plant communities in stretches of the surveyed watercourses.

\section{Association Ceratophylletum demersi Corillion 1957}

This was the only community dominated by pleustophytes. The association is defined with the characteristic species $C$. demersum, which had the highest abundance and was accompanied by $M$. spicatum and $P$. nodosus. Species richness was high. The distribution of this association was narrow, since it was found only in the six most lentic stretches of the rivers Krka and Struga (Figures 1 and 6).

\section{Association Potametum denso-nodosi de Bolós 1957}

This vegetation type is dominated by the species $P$. nodosus, which has both natant and submerged leaves, but the former may be absent in running water. Clusters 2 and 3 encompassed the majority of stretches except from the Krka River, where P. nodosus was co-dominant with $C$. demersum and Najas marina. Cluster 4 encompassed stands with the most prominent dominance of characteristic species. They were recorded in three watercourses from three hydrological regions (Temenica, Pavlovski potok, and Vipava) (Figures 1 and 6). Three types of this community were recorded, which were classified into three clusters. 


\section{Association Myriophylletum verticillati Gaudet ex Šumberová in Chytrý 2011}

This vegetation type is dominated by $M$. verticillatum. These stands were the most species-rich and were only present in the river Struga.

Association Potamo pectinati-Myriophylletum spicati Rivas Goday 1964

The far most abundant species in this community was M. spicatum, which was also the most common macrophyte in the studied watercourses. This association was found in 31 stretches in watercourses from all three regions of Slovenia (Figures 1 and 6). A smaller cluster was recorded in the lower part of the river Ščavnica in the most eastern margin of the study area and differed from the larger cluster due to high abundance of the amphiphyte Butomus umbellatus, which was present in $f$. aquatica and $f$. terrestris. The third largest group of 87 stretches was classified into a sub-optimally developed form of the association Potamo pectinati-Myriophylletum spicati. In these stands, the characteristic species M. spicatum was the most abundant species, which had about two-fold the cover of the type described below, but still lower abundance than what is required for classification into association $(\geq 50 \%)$. The second most abundant species was $P$. nodosus. This was the species-poorest vegetation type (4.2). The stands had the same distribution pattern as the stands of optimally developed association. Based on these indicators, we classified this group into the association Potamo pectinati-Myriophylletum spicati. This was the most frequently recorded association.

\section{Community with Myriophyllum spicatum}

We classified this second largest cluster (Figure 5) into a suboptimal form of the above-described association, since the characteristic species did not reach the abundance for classification into association. The subdominant species were Phalaris arundinacea and $P$. nodosus, with significantly lower abundances.

\section{Association Potametum pectinati Carstensen ex Hilbig 1971}

This association is dominated by P. pectinatus. This plant association occurred only in eight stretches in the rivers Krka, Borovniščica, Ižica, and Stržen. Nonetheless, the characteristic and dominant species P. pectinatus was very common.

\section{Association Potametum crispi von Soó 1927}

The dominant species in this association is P. crispus (Table 2, 36\%), which is present in all 27 stretches and is about three times more abundant than M. spicatum (13\%). It was determined in the rivers Krka, Sotla, Temenica, Hočki potok, Polskava, Pavlovski potok, and even Vipava. The average number of species was low (7.8).

\section{Association Potametum perfoliati Miljan 1933}

This plant association is defined by the dominance of the characteristic species $P$. perfoliatus, which was two times more abundant than the second most abundant species $M$. spicatum (22\%). Species richness was moderate (average 10.0). The third most abundant species in these 23 stretches was P. crispus. It was detected in the lower flow of Kolpa and in Rak, Vipava, Pesnica, Rinža, and Ižica (Figures 1 and 6).

\section{Association Potametum natantis Hild 1959}

This plant association is defined by the characteristic and dominant species with floating leaves, P. natans, which was the most abundant (51\%). The sub-dominant species were N. luteum and P. lucens. Species richness and total abundance were moderate. It was detected in 18 stretches in Krka, Ljubljanica and along the lower flow of the river Ižica.

\section{Association Elodeetum canadensis Nedelcu 1967}

This community is dominated by the invasive alien species E. canadensis. It developed in Krka, Temenica, Ljubljanica, Ižica, and Stržen. Species richness was moderate.

Association Nymphaeo albae-Nupharetum luteae Nowiński 1927

This community is dominated by the large-sized floating-leaved macrophyte N. luteum, which often develops only submerged leaves in running waters. The distribution of this association in surveyed rivers is limited to the river Stržen in the Cerkniško polje and to the river Ščavnica in the Pannonian region, while single stretches were recorded in the river Vipava (Po lowland) and in the river Rinža (Dinarides).

Association Potamo crispi-Ranunculetum trichophylli Imchenetzky 1926 
These stands are dominated by Ranunculus trichophyllus. It occurs in oligo-mesotrophic to eutrophic water bodies, such as alluvial pools and ditches. It is often accompanied by Eleocharis acicularis. It was distributed in 32 stretches in the rivers on karst poljes (Veliki Obrh, Stržen, Rak, Unica), which have an extremely fluctuating water tables, as they sometimes even run dry, and in two stretches of the river Vipava.

Association Polygonetum hydropiperis Passarge 1965

This vegetation type is usually dominated by Polygonum hydropiper or P. mite. It occurred only in seven stretches in the lower part of the river Ščavnica.

Association Phragmitetum australis Savič 1926

In the riverbeds of the surveyed watercourses, this association was sub-optimally developed. The distribution of these stands is ubiquitous, as P. australis is the dominant species. It occurred in 42 stretches in watercourses of the coastal part of Slovenia (Rižana), Po lowland (Vipava) in central Slovenia, as well as in the Pannonian region.

Association Glycerio-Sparganietum neglecti Koch 1926

The community dominated by Sparganium erectum agg. was detected in 18 stretches and included stands dominated by the species S. erectum, S. neglectum, and S. microcarpum.

Association Schoenoplectetum lacustris Chouard 1924

This community is dominated by the tall-growing species Schoenoplectus lacustris that forms sparse stands. Its distribution was limited to the rivers on karst poljes (Mali Obrh, Stržen, Unica), with extremely fluctuating water tables.

Association Phalaridetum arundinaceae Libbert 1931

Stands of this association are dominated by Phalaris arundinacea. They were found in watercourses in all three regions.

Association Oenantho aquaticae-Rorippetum amphibiae Lohmeyer 1950

This association is dominated by Rorippa amphibia, which often forms dense monospecific stands. It was recorded in the river Stržen and in two Pannonian rivers.

Association Alopecuro-Alismatetum plantaginis-aquaticae Bolbrinker 1984

This association includes stands with the characteristic and dominant species Alisma plantago-aquatica. It was found in five stretches in Sotla, Hočki potok, and Pavlovski potok.

Association Sagittario sagittifoliae-Sparganietum emersi Tüxen 1953

This association includes stands dominated by Sagittaria sagittifolia and S. emersum, respectively, which are both characteristic and dominant species of this association. Stands of this association were recorded in the river Ljubljanica and its tributary in central Slovenia, and in the river Ščavnica in the northeastern edge of the study area.

Association Eleocharito palustris-Hippuridetum vulgaris Passarge 1964

This vegetation type is represented by stands of Hippuris vulgaris. This association was the rarest among the studied associations since it only occurred in the river Ižica in central Slovenia.

Association Glycerio notatae-Veronicetum beccabungae Landucci et al. 2020

Stands dominated by Veronica beccabunga were classified to the association Glycerio notatae-Veronicetum beccabungae, which was defined in the year 2020. The subdominant species were Juncus effusus, P. australis, and Agrostis stolonifera. These stands were among the species-poorest (average 4.3) in our study. This association was rare, since it was only recorded in four stretches of the upper part of the river Temenica in central Slovenia.

Association Beruletum erectae Roll 1938

This association is dominated by the amphiphyte macrophyte Berula erecta. We found this community in three different forms considering floristic composition, one with the co-dominant Callitriche spp., the most common with the subdominant Callitriche spp., and the third, where B. erecta was the most dominant species. This association was recorded in 18 different watercourses all over Slovenia in all the regions, from the coastal part and Po lowland to the most eastern watercourses in the Pannonian lowland.

Association Mentho aquaticae-Oenanthetum fistulosae ass. nova

This association has not yet been described, so we define it for the first time here in this contribution. This new description is also the consequence of its limited distribution, as 
it was only recorded in five stretches of the river Mali Obrh. This river flows on the Loško polje, which is a karst polje, a feature found only in the Dinaric region within Europe, for which exceptional water level fluctuations are characteristic, as sometimes the entire area may even run dry. Stands of this community are dominated by the characteristic species Oenanthe fistulosa, accompanied with numerous amphiphytes from the class PhragmitoMagnocaricetea, which represent the majority in number and abundance. This was the third richest plant community in our study.

Holotypus hoc loco: Oenanthe fistulosa 63\%, Mentha aquatica 38\%, Juncus articulatus $38 \%$, Phalaris arundinacea 15\%, Alisma spp. 15\%, Rorippa amphibia 15\%, Caltha palustris 3\%, Potamogeton lucens 15\%, Schoenoplectus lacustris 15\%, Lycopus europaeus 3\%, Sium latifolium 3\%. (GK Coordinates: 459,376, 61,043; altitude: $570.2 \mathrm{~m}$ a.s.1.; slope: 0.58; current velocity: 1; length: $100 \mathrm{~m})$.

Association Rumici crispi-Agrostietum stoloniferae Moor 1958

This association occurs in sites that are frequently dry. In fact, they are mostly inundated at moderate or high-water levels. This association was recorded in the river Mali Obrh in karst polje and in two streams in the Pannonian lowland.

\section{Species-poorest sections with lowest abundance of macrophytes}

This group of stretches could not be classified into any plant communities due to the low abundance and various ecology of the present species. This was by far the largest group of stretches (Figure 5), which encompassed one quarter of the total set of the recorded stretches. This group was among the species-poorest groups (6.5 species on average) with a very low abundance value. The most common species in this type were marsh species (helophytes) P. arundinacea, Lytrum salicaria, and Myosotis scorpioides, found sporadically close to the banks within these stretches regardless of the region. This type is scattered along the entire set of the studied watercourses.

\section{Discussion}

\subsection{Species Presence and Abundance}

High heterogeneity of sub-catchments of the surveyed watercourses resulted in high heterogeneity of environmental parameters and consequently high vascular plant diversity and low total share of species with a wide ecological valence. This environmental heterogeneity provides high habitat diversity, as shown in the case of macrophyte diversity in ponds [76]. The meta-analysis of aquatic macrophytes on a global scale revealed that the majority of macrophyte species are distributed within narrow ranges, and only $1.21 \%$ of the total 3457 macrophyte species are widely distributed [77]. The most abundant species in the surveyed Slovenian watercourses were M. spicatum, P. arundinacea, P. nodosus, $B$. erecta, P. perfoliatus, alien species E. canadensis, P. crispus, P. pectinatus, N. luteum, P. natans, and S. lacustris. All of these species are known to have wide ecological ranges [78,79]. Some of them even became invasive in different parts of the world. The presence and abundance of these invasive species depend on their potential for introduction in certain environments and environmental limitations to their distributions [80]. Among the most abundant species detected in this study was the alien species E. canadensis. However, it does not exhibit an invasive character in the surveyed watercourses, since the environmental diversity of these watercourses prevents its spreading [81]. In addition, E. canadensis is indicative of impacted lowland sites [82], as also revealed in this study.

In the surveyed watercourses, we detected a relatively low share of submerged plants. This is possibly due to the low average stream order of these watercourses and thus shading of riverbeds with riparian vegetation. Species with amphibious character are an especially important component of karst watercourses, where extreme water level fluctuations present a factor of permanently changing environmental conditions. These changes do not only present stress for plants, but also disturbances that result in dieback of submerged species. Thus, only well-adapted amphibious species and cosmopolites may withstand these changes [39]. In the case of northern European rivers, less than half of aquatic plant species exhibited an amphibious character [83]. Among the more abundant 
species found in the surveyed watercourses, P. arundinacea, B. erecta, N. luteum, and S. lacustris may develop different growth forms in addition to numerous low-growing amphibious species like M. aquatica, R. amphibia, V. anagallis-aquatica, and M. scorpioides agg., which may also contribute significantly to plant abundance. Multiple environmental changes during water level fluctuations like $\mathrm{CO}_{2}$ concentration, light intensity and quality, temperature, and osmotic stress may trigger the development of a new, better-adapted growth form or leaves [84]. In addition, these fluctuations also affect environmental conditions for ecosystem processes, especially the exchange of substances between sediments and water, and mineralization rates [85], and thus the availability of nutrients in water [86]. Changes are most pronounced during floods, when nutrients are released from the terrestrial systems into water. Due to intensive mineralization rates, the sediments of intermittent water bodies usually contain a lower proportion of organic matter and consequently a lower nutrient content [87], which may also affect species composition. Among growth forms, we detected a somewhat lower share of helophytes and floating-leaved plants, while the lowest share was seen for free-floating vascular plant taxa. This was a consequence of the environmental properties of these watercourses that mainly present tributaries of larger rivers, such as rivers Sava and Drava.

\subsection{The Relationships between Macrophyte Presence and Abundance, and Environmental Factors}

In our study, spatial parameters explained the greatest share of species presence and abundance variability. This is expected, since according to the research of Tapia Grimaldo et al. [88], spatial variables may be used as a proxy for various environmental variables that are important for defining macrophyte communities. The significant contribution of distance from the source to the explained variance is partly a consequence of the river continuum effect [89] that is based on discharge gradient, current velocity, flow pattern, bed, bank, and community structure along the river course. Considering single parameters (marginal effects), altitude was of equal importance. Since we excluded the alpine region from our research, the most pronounced altitudinal gradient in the surveyed watercourses was seen for the karst intermittent watercourses that flow through different poljes along the Idrija fault which are located at different altitudes and host different plant species [39]. Kennedy et al. [90] showed that the main environmental parameters for shaping macrophyte community composition and diversity are altitude and stream order, along with some chemical parameters.

Correlation analysis between the environmental parameters and species diversity and abundance showed highly significant results (Table 1). Altitude has been shown to be a strong predictor of aquatic macrophyte diversity irrespective of geographical location [91] and is usually negatively related with species diversity [42]. However, in our study, we found positive correlations between macrophyte species diversity and altitude. The strong negative relationship with current velocity found in our study is in accordance with the results, gathered in the survey of middle-sized streams in Latvia, where the highest macrophyte diversity was determined in streams with low water velocity and gravelly substrate, while the species-poor macrophyte communities were characteristic for streams with high water velocity and sandy substrate [92]. The most sensitive macrophytes to high water velocities are macrophytes that are anchored to the sediment, while macrophytes with a free-floating growth form are the least sensitive [51]. The latter may also be passively transported along the river flow, while the former might be mechanically damaged or loaded with sediment. Low to moderate velocities have a beneficial effect on growth, as they increase the availability of carbon dioxide and nutrients, while higher speeds represent mechanical stress and thus have a negative effect [93]. This is in accordance with the intermediate disturbance hypothesis, which presumes that maximum species richness occurs under moderate disturbance regime [94]. In addition, the current supports plant communities by transport of plant propagules along the watercourse [24]. 


\subsection{Plant Communities}

Syntaxonomic scheme of the studied plant communities

1. Class Lemnetea O. de Bolòs et Masclans 1955

1.1. Alliance Stratiotion Den Hartog et Segal 1964

1 Association Ceratophylletum demersi Corillion 1957

2. Class Potamogetonetea Klika in Klika et Novák 1941

2.1. Alliance Potamogetonion Libbert 1931

2 Association Potametum denso-nodosi de Bolós 1957

3 Association Myriophylletum verticillati Gaudet ex Šumberová in Chytrý 2011

4 Association Potamogetono pectinati-Myriophylletum spicati Rivas Goday 1964

5 Community with Myriophyllum spicatum

6 Association Potametum pectinati Carstensen ex Hilbig 1971

7 Association Potametum crispi Soó 1927

8 Association Potametum perfoliati Miljan 1933

9 Association Potametum natantis Hild 1959

10 Association Elodeetum canadensis Nedelcu 1967

2.2. Alliance Nymphaeion albae Oberdorfer 1957

11 Association Nymphaeo albae-Nupharetum luteae Nowiński 1927

2.3. Ranunculion aquatilis Passarge ex Theurillat in Theurillat et al. 2015

12 Association Potamo crispi-Ranunculetum trichophylli Imchenetzky 1926

3. Class Bidentetea tripartitae Tüxen et al. ex von Rochow 1951

3.1. Alliance Bidention tripartitae Nordhagen ex Klika et Hadač 1944

13 Association Polygonetum hydropiperis Passarge 1965

4. Class Phragmito-Magnocaricetea Klika in Klika et Novák 1941

4.1. Alliance Phragmition communis Koch 1926

14 Association Phragmitetum australis Savič 1926

15 Association Glycerio-Sparganietum neglecti Koch 1926

16 Association Schoenoplectetum lacustris Chouard 1924

17 Association Phalaridetum arundinaceae Libbert 1931

4.2. Alliance Eleocharito palustris-Sagittarion sagittifoliae Passarge 1964

18 Association Oenantho aquaticae-Rorippetum amphibiae Lohmeyer 1950

19 Association Alopecuro-Alismatetum plantaginis-aquaticae Bolbrinker 1984

20 Association Sagittario sagittifoliae-Sparganietum emersi Tüxen 1953

21 Association Eleocharito palustris-Hippuridetum vulgaris Passarge 1964

4.3. Alliance Glycerio-Sparganion Br.-Bl. et Sissingh in Boer 1942

22 Association Glycerio notatae-Veronicetum beccabungae Landucci et al. 2020

23 Association Beruletum erectae Roll 1938

24 Association Mentho aquaticae-Oenanthetum fistulosae ass. nova

5. Class Molinio-Arrhenatheretea Tx. 1937

5.1. Alliance Potentillion anserinae Tx. 1947

25 Association Rumici crispi-Agrostietum stoloniferae Moor 1958

The surveyed stretches differed greatly regarding species composition and abundance, and we classified these assemblages into 25 different associations. Most of the determined associations are widespread in the surveyed watercourses, with the exception of 7 of them that occur more locally, 3 out of these in karst poljes.

The association Ceratophylletum demersi was the only community dominated by pleustophytes, occurring in the studied watercourses, and was detected in six stretches. It usually occurs in waterbodies with no or only slow current, in eutrophic to hypertrophic wa- 
ter, which can also reach high turbidity [65]. However, in lakes, $C$. demersum may also play an important role in stabilization and maintenance of a clear-water state at high $\mathrm{P}$ concentrations [95].

The association Potametum denso-nodosi occurs in watercourses with low flow velocity or in artificial channels, mostly with water depths of 30-60 cm, as was also the case in our study. These habitats are usually frequently disturbed, while sediments are mainly mineral [66]. The dominant species is P. nodosus. This species is widespread and develops both natant and submerged leaves [79].

The association Myriophylletum verticillati occurs in mesotrophic to eutrophic clear water, e.g., in channels and lentic sections of streams [66]. M. spicatum and M. verticillatum thrive in waters with high calcium contents [96].

The association Potamo pectinati-Myriophylletum spicati was the species-poorest vegetation type, which indicated the competitive character of the dominant species M. spicatum with a broad ecological range [81]. Large-branched specimens that produce dense stands and dispersion by fragmentation present a competitive advantage over smaller species [97]. Thus, it is most common in places with regular disturbances. It also tolerates turbid waters and even desiccation of its habitat for a short period [66].

Community with M. spicatum formed the second largest cluster of stretches. This community was sub-optimally developed, since the characteristic species did not reach the level of abundance for classification into association. The subdominant species were $P$. arundinacea and $P$. nodosus, with significantly lower abundances.

The association Potametum pectinati thrives in eutrophic and hypertrophic waters with high turbidity and was mostly found in the middle and lower parts of watercourses. This association is dominated by P. pectinatus, which has high phenotypic plasticity [79]. Its reproduction is generally vegetative. Therefore, tubers play an important role in survival of its populations [98].

The association Potametum crispi was found in different parts of Slovenia, mainly in the watercourses that are not very deep. The community is typical for waters loaded with nutrients [66].

The association Potametum perfoliati was defined by the dominance of the characteristic species P. perfoliatus, which is indicative of a wide range of nutrient conditions and $\mathrm{pH}$ [99].

The association Potametum natantis was only found in few stretches of three lowland rivers. This species-poor vegetation type is dominated by $P$. natans, which forms dense stands with broad leaves, floating on the water surface [79]. It mostly occurs in mesotrophic, but also in oligotrophic or eutrophic water bodies, which are $20-100 \mathrm{~cm}$ deep, with no or slow current, e.g., in alluvial pools, channels, and lentic sections of streams [66].

The association Elodeetum canadensis is dominated by the invasive alien species Elodea canadensis. It was found only in about $4 \%$ of the surveyed stretches. This species prefers deeper eutrophic water bodies like channels and lentic sections of streams. It was not found in karst watercourses, since it does not tolerate drying [39]. Although this vegetation type is considered as species-poor, species richness in our case was moderate (10.7), which indicated low invasiveness of the characteristic species in the studied watercourses [81]. They mostly occurred in central Slovenia.

The association Nymphaeo albae-Nupharetum luteae is characteristic for the river Stržen in the Cerkniško polje (Dinarids) and for the river Ščavnica in the Pannonian region. It tolerates high water level fluctuations, which mark the water regime in the Cerkniško polje [100]. According to Šumberová [66], it usually develops in mesotrophic to eutrophic water of alluvial pools, channels, and lentic sections of streams. This community is dominated by the large-sized floating-leaved macrophyte Nuphar luteum, which mainly develops submerged leaves in running waters. This association was mostly found in the river Stržen in the Cerkniško polje, and in the river Ščavnica in the Pannonian region.

The association Potamo crispi-Ranunculetum trichophylli is the only association from this alliance. It encompasses the vegetation of aquatic plants, that is mainly present in rivers on karst poljes with an extremely fluctuating water table [101]. 
The association Polygonetum hydropiperis is usually dominated by P. hydropiper or P. mite. It colonizes the banks of rivers and streams, seasonally flooded pools in river floodplains, ditches, and channels, where soils tend to dry out quickly [67]. This association was rare in the studied watercourses.

Monospecific stands of the association Phragmitetum australis consist of tall and dense shoots of $P$. australis [102]. This species has a broad ecological range, occurring in oligotrophic to eutrophic, acidic to basic sites [68], having low regional bioindicator potential [103]. It is widely distributed from $70^{\circ} \mathrm{N}$ to the tropics [104]. It occurs in the littoral, along the watercourses, channels, and in deltas, in up to 2-m-deep waters [100]. In the surveyed riverbeds, this association was sub-optimally developed. It was abundant in the riparian zone, which was, however, not the subject of our research.

The association Glycerio-Sparganietum neglecti includes stands dominated by the species S. erectum, S. neglectum, and S. microcarpum. In some floras, these species are considered as subspecies of $S$. erectum, while in others, they are treated as independent species $[70,105]$. They have a very similar morphology, distribution, and habitats, which are overlapping, so they had been frequently misidentified or not distinguished from each other. Therefore, it was not possible to define three different associations [106]. They usually thrive in shallow mesotrophic to eutrophic water bodies, in ditches and channels with slowly running water, as well as in lentic sections on lower river courses. The dominant S. erectum agg. develops aerial and long submerged floating leaves, which are tolerant to moderate current velocity. Usually, optimal water level is $10-60 \mathrm{~cm}$, but sites may dry out for short periods in summer $[43,68]$.

The association Schoenoplectetum lacustris is dominated by the tall-growing species S. lacustris that favors mesotrophic to eutrophic water, constantly wet conditions and is usually found deeper than P. australis [70]. It often colonizes a transitional zone between the open water and reed vegetation. The distribution of this association was limited to rivers on karst poljes.

The association Phalaridetum arundinaceae, which is dominated by P. arundinacea, previously classified to the association Rorippo-Phalaridetum [68]. This association occurred on stream banks of the middle reaches of watercourses with high current velocity and is characterized by species tolerant of disturbance. Landucci et al. [70] classified stands dominated by P. arundinacea into one single association Phalaridetum arundinaceae, which was assigned to the alliance Phragmition communis since the floristic differences between these associations are too small.

The association Alopecuro-Alismatetum plantaginis-aquaticae was only found in five stretches. It usually occurs in shallow water in sites, which are seasonally dry. Habitats are typically mesotrophic to eutrophic and inundated by up to $50 \mathrm{~cm}$. However, occurrences on wet and occasionally inundated soil are also common [68]. In our study, this association was found in the watercourses of the Pannonian area with such character.

The association Sagittario sagittifoliae-Sparganietum emersi includes stands dominated by S. sagittifolia and S. emersum, respectively, which are both characteristic and dominant species of this association. In rivers, both species produce different leaf forms, namely submerged or emergent, or even partly floating leaves on the water surface. This association favors up to $120 \mathrm{~cm}$ deep eutrophic waters [68]. In summer, the water table can decrease and expose the bottom. However, these dominant species can regenerate from their underground organs.

The association Eleocharito palustris-Hippuridetum vulgaris is represented by stands of H. vulgaris. In stretches with low current velocity, this species forms dense stands [107]. In deep waters, it appears in the submerged form, while in shallow waters, it occurs in the emergent form. It thrives in calcium-rich waters and is often found in cool waters. In general, the number of localities is low and is decreasing due to eutrophication and spread of competitively stronger plants [68]. This association was among the rarest and occurred only in the river Ižica in central Slovenia. 
The association Glycerio notatae-Veronicetum beccabungae is dominated by $V$. beccabunga and was defined in 2020 due to the previously invalidly published names [70]. The subdominant species were Juncus effusus, P. australis, and A. stolonifera. These stands were rare and species-poor.

The association Beruletum erectae, which is dominated by the amphiphyte B. erecta, was found in 56 stretches of 18 watercourses in all the surveyed regions. The dominant species and consequently the association thrive in waters rich in nutrients and calcium, and can be found in different forms, namely in emergent stands in shallow water or on wet banks, in stands with leaves, partly floating on the surface in slow streams, and in submerged stands with strongly branched stems in fast streams [68], as was also the case in our study.

The association Mentho aquaticae-Oenanthetum fistulosae is a species-rich, newly defined association, limited to five stretches in the river Mali Obrh on Loško polje. Stands of this community are dominated by the low stature amphibious species $O$. fistulosa, which thrived in the company of numerous other amphiphytes.

The flood-meadow association Rumici crispi-Agrostietum stoloniferae is species-poor because of the dominance of the taxon A. stolonifera agg., which forms dense stands [69]. This association occurred only in six stretches in sites that are frequently dry, but mostly inundated at moderate or high-water levels.

\section{Conclusions}

High heterogeneity of the surveyed watercourses, their catchments, and environmental parameters resulted in high diversity of vascular plants and consequently in high diversity of plant communities they form. We found high heterogeneity of aquatic vegetation and low total share of species with a wide ecological valence. We determined a total of 87 vascular plants among which $36 \%$ of total abundance belonged to submerged macrophytes, $30 \%$ to amphiphytes, $18 \%$ to helophytes, 3\% to floating-leaved plants, and only $3 \%$ to pleustophytes. The most abundant species was $M$. spicatum with a $12 \%$ share, followed by P. arundinacea and P. nodosus. Spatial parameters explained the highest share of species presence and abundance variability. The examined river stretches host 25 different associations belonging to 5 classes and 9 alliances, which are mostly distributed in different hydro-ecoregions. Seven plant associations had local distribution, and three of them were only found on karst poljes. This distribution pattern reveals specific environmental conditions in these karst poljes and lack of regionality elsewhere.

Author Contributions: Conceptualization, A.G. and I.Z.; methodology, M.H., A.G., U.K. and I.Z.; investigation: A.G., M.G. and U.K.; validation: M.H., A.G., M.G. and U.K., I.Z.; writing-original draft preparation M.H., A.G. and I.Z.; writing-review and editing, A.G. and I.Z.; visualization, A.G., M.H. and I.Z.; supervision, A.G. and I.Z.; project administration, A.G. and U.K.; funding acquisition, A.G. All authors have read and agreed to the published version of the manuscript.

Funding: This research was funded by Ministry of Higher Education, Science and TechnologyResearch programs Biology of plants (P1-0212) and Young researchers (3311-04-831246) (Slovenia).

Institutional Review Board Statement: Not applicable.

Informed Consent Statement: Not applicable.

Data Availability Statement: Data are stored within the documentation of P1-0212 Research program. Data are available on special request.

Acknowledgments: The authors thank to Mateja Grašič for reviewing the manuscript.

Conflicts of Interest: The authors declare no conflict of interest. The funders had no role in the design of the study; in the collection, analyses, or interpretation of data; in the writing of the manuscript, or in the decision to publish the results. 


\section{Appendix A}

Table A1. Synoptic table of the clusters classified into plant communities. Their dominant (orange) and subdominant (yellow) species are presented in average values of cover-abundance values (\%). 0 stands for values $<0.5$.

\begin{tabular}{|c|c|c|c|c|c|c|c|c|c|c|c|c|c|c|c|c|c|c|c|c|c|c|c|c|c|c|c|c|c|c|c|c|c|c|}
\hline Cluster Number & 1 & 2 & 3 & 4 & 5 & 6 & 7 & 8 & 9 & 10 & 11 & 12 & 13 & 14 & 15 & 16 & 17 & 18 & 19 & 20 & 21 & 22 & 23 & 24 & 25 & 26 & 27 & 28 & 29 & 30 & 31 & 32 & 33 & 34 \\
\hline number of stretches & 6 & 31 & 10 & 10 & 5 & 31 & 6 & 8 & 7 & 12 & 26 & 6 & 109 & 4 & 4 & 5 & 226 & 30 & 5 & 27 & 32 & 23 & 18 & 87 & 18 & 13 & 15 & 7 & 38 & 19 & 11 & 18 & 4 & 35 \\
\hline \multicolumn{35}{|c|}{ dominant species of the plant associations } \\
\hline Ceratophyllum demersum & 63 & 37 & 36 & & & . & & 5 & & & . & $\cdot$ & . & & & 3 & 0 & & . & 1 & & & 2 & 0 & & & & & 1 & . & & . & & \\
\hline Potamogeton nodosus & 22 & 31 & 63 & 66 & . & 16 & 39 & 13 & 6 & . & 0 & . & 4 & & 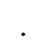 & 1 & 1 & 4 & . & 4 & & 9 & 15 & 18 & & . & 6 & 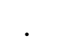 & & 1 & & . & 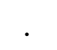 & 3 \\
\hline $\begin{array}{l}\text { Myriophyllum } \\
\text { verticillatum }\end{array}$ & 3 & . & & 2 & 63 & . & . & 2 & . & . & . & . & 1 & . & . & . & 0 & . & . & 3 & 0 & & . & 0 & . & 3 & . & . & 1 & . & . & 0 & . & 2 \\
\hline Myriophyllum spicatum & 26 & 27 & 22 & 23 & 39 & 64 & 63 & 21 & 42 & 9 & 3 & . & 15 & . & . & . & 1 & 11 & . & 13 & 4 & 22 & 19 & 33 & 5 & 3 & 4 & . & 3 & 2 & . & 12 & 13 & 7 \\
\hline Potamogeton pectinatus & 18 & 24 & 29 & . & 15 & 2 & 59 & 63 & 39 & . & 0 & . & 0 & . & . & 14 & 0 & . & . & 0 & 1 & 6 & 6 & 1 & . & . & . & . & 1 & 0 & . & 8 & . & 1 \\
\hline $\begin{array}{c}\text { Polygonum } \\
\text { hydropiper } / \text { mite }\end{array}$ & 1 & . & . & 1 & 2 & 2 & 5 & 6 & 45 & 6 & 2 & 1 & 0 & . & . & 26 & 0 & 1 & . & 2 & . & . & 8 & 0 & . & 2 & 2 & . & 0 & 1 & 1 & . & . & 1 \\
\hline Phragmites australis & 9 & 1 & 1 & 8 & 13 & 2 & & 4 & & 63 & 3 & 3 & 1 & 8 & 13 & 1 & 1 & 22 & & 1 & 0 & 2 & 0 & 1 & . & 3 & 3 & 1 & 4 & 1 & 5 & & . & 2 \\
\hline Phalaris arundinacea & 7 & 2 & 0 & 20 & 33 & 7 & 28 & 12 & 42 & 2 & 38 & 7 & 5 & 2 & . & 9 & 4 & 4 & 19 & 11 & 6 & 9 & 13 & 2 & 5 & 69 & 5 & . & 9 & 9 & 15 & 2 & . & 7 \\
\hline Agrostis stolonifera agg. & . & . & . & . & . & . & 22 & . & 13 & & 5 & 42 & 1 & 4 & 8 & & 2 & 2 & 3 & 2 & & 2 & 3 & 0 & & 2 & 2 & . & 2 & 4 & 1 & 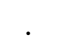 & . & 1 \\
\hline Rorippa amphibia & . & . & . & & . & 0 & 8 & . & 0 & - & 3 & . & 0 & 44 & & & 1 & 4 & 9 & . & 5 & 0 & 0 & & 2 & 4 & 6 & . & & 0 & . & 0 & . & \\
\hline Veronica beccabunga & 1 & . & . & 2 & 4 & . & . & 1 & & . & 2 & . & 0 & $2 x$ & 38 & & 1 & . & . & . & 0 & . & 4 & 0 & . & 2 & 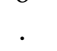 & . & 1 & . & . & . & . & 1 \\
\hline Alisma plantago-aquatica & 1 & . & . & 1 & 1 & 2 & 8 & 1 & 5 & 5 & 1 & 2 & 0 & 10 & 0 & 29 & 1 & 2 & . & 3 & & $\dot{0}$ & 6 & 1 & . & 3 & 2 & & 1 & 2 & $\dot{0}$ & . & . & 2 \\
\hline Oenanthe fistulosa & . & . & . & . & . & . & . & . & 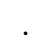 & . & . & . & . & . & . & 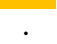 & 0 & . & 63 & & 4 & & . & . & 3 & 5 & & . & . & . & . & . & . & . \\
\hline Potamogeton crispus & 3 & 0 & 0 & 7 & . & 2 & 19 & 0 & 18 & 6 & 1 & . & 3 & . & . & 1 & 1 & 2 & . & 36 & 13 & 13 & 9 & 2 & . & 0 & 0 & 0 & 3 & 5 & 0 & 3 & 8 & 9 \\
\hline Ranunculus trichophyllus & 3 & 7 & 12 & . & . & . & . & 2 & & . & . & 3 & 1 & . & . & . & 1 & 1 & . & 2 & 27 & 3 & 2 & 2 & 1 & 0 & 5 & & 2 & 7 & . & 1 & 5 & 2 \\
\hline Potamogeton perfoliatus & 5 & 8 & 2 & . & . & 6 & 4 & 10 & 8 & 1 & 1 & . & 2 & . & . & . & 1 & 1 & . & 0 & 7 & 43 & & 3 & 15 & . & 0 & 31 & 0 & 5 & . & 13 & 1 & 9 \\
\hline Sparganium erectum agg. & 6 & 0 & 3 & 8 & 5 & 2 & 13 & 10 & & 11 & 3 & 11 & 1 & . & . & 3 & 1 & 5 & . & 4 & . & 1 & 41 & 2 & & . & 2 & . & 3 & 10 & 15 & & . & 1 \\
\hline Schoenoplectus lacustris & 3 & 11 & 5 & 4 & . & 1 & . & 7 & & . & 3 & . & 1 & 2 & . & . & 1 & 2 & 4 & . & 12 & 2 & 1 & 1 & 57 & . & 5 & & 1 & 1 & . & 15 & . & 1 \\
\hline Nuphar luteum & . & . & . & 12 & . & 0 & 23 & 5 & & 3 & . & . & 0 & . & . & . & 1 & 17 & . & . & 0 & 1 & . & 0 & 4 & . & 65 & & & 7 & . & 19 & & 6 \\
\hline Callitriche spp. & 1 & . & . & 2 & 2 & 1 & 1 & 7 & 32 & 0 & 0 & . & 0 & . & . & 6 & 1 & . & 1 & 4 & 4 & 0 & 5 & . & . & 10 & & 38 & 15 & 19 & 4 & 6 & 27 & 5 \\
\hline Berula erecta & 1 & 0 & 0 & 3 & 17 & 0 & 1 & 11 & & 8 & 3 & 1 & 1 & . & . & . & 1 & 3 & . & 4 & . & 1 & 4 & 0 & . & 5 & 4 & 38 & 24 & 13 & 65 & 7 & 27 & 3 \\
\hline Sparganium emersum & 8 & 6 & . & 8 & 8 & 4 & 5 & 11 & 16 & 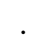 & . & . & 0 & . & . & & 1 & 3 & . & 1 & . & 1 & 1 & 0 & . & 3 & 7 & 29 & 1 & 47 & . & 18 & 1 & 10 \\
\hline Butomus umbellatus & . & . & . & . & . & . & 46 & & 13 & & 1 & . & 0 & . & . & & 1 & 0 & . & . & 0 & 2 & . & & . & . & 0 & & . & . & . & . & . & \\
\hline Potamogeton natans & 9 & 1 & . & . & 8 & 1 & . & 21 & & 11 & . & . & 0 & . & . & . & 0 & 7 & . & 2 & 3 & 9 & . & 1 & 1 & 1 & . & 0 & . & 15 & 3 & 51 & 10 & 13 \\
\hline
\end{tabular}


Table A1. Cont.

\begin{tabular}{|c|c|c|c|c|c|c|c|c|c|c|c|c|c|c|c|c|c|c|c|c|c|c|c|c|c|c|c|c|c|c|c|c|c|c|}
\hline Cluster Number & 1 & 2 & 3 & 4 & 5 & 6 & 7 & 8 & 9 & 10 & 11 & 12 & 13 & 14 & 15 & 16 & 17 & 18 & 19 & 20 & 21 & 22 & 23 & 24 & 25 & 26 & 27 & 28 & 29 & 30 & 31 & 32 & 33 & 34 \\
\hline number of stretches & 6 & 31 & 10 & 10 & 5 & 31 & 6 & 8 & 7 & 12 & 26 & 6 & 109 & 4 & 4 & 5 & 226 & 30 & 5 & 27 & 32 & 23 & 18 & 87 & 18 & 13 & 15 & 7 & 38 & 19 & 11 & 18 & 4 & 35 \\
\hline \multicolumn{35}{|c|}{ dominant species of the plant associations } \\
\hline Hippuris vulgaris & & $\cdot$ & . & . & 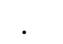 & . & . & . & . & . & . & 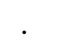 & & . & . & . & 1 & 1 & . & & 7 & $\cdot$ & $\cdot$ & & 1 & . & 4 & 0 & 1 & & & 7 & 63 & 2 \\
\hline Elodea canadensis & 1 & 0 & 2 & 0 & 8 & 3 & . & 9 & . & . & . & . & 0 & . & . & . & 1 & . & . & 10 & . & 2 & 2 & 0 & & . & . & . & 2 & 5 & 3 & 15 & 38 & 49 \\
\hline subdominant taxa & . & . & . & . & . & . & . & . & . & . & . & . & & . & . & . & . & . & . & & . & . & . & & 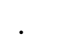 & . & . & . & . & . & . & . & . & $\cdot$ \\
\hline Najas marina & . & 14 & 34 & . & . & 1 & 5 & 0 & . & . & . & . & 0 & . & . & . & 0 & . & . & 0 & . & . & 1 & 0 & . & . & . & . & . & . & 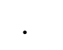 & . & . & . \\
\hline Zannichellia palustris & . & . & $\cdot$ & 10 & 8 & . & . & . & . & . & . & . & 0 & . & . & . & 0 & . & . & . & . & 0 & . & 0 & & 5 & . & . & 2 & . & 0 & . & . & . \\
\hline Potamogeton berchtoldii & . & . & . & . & 26 & 2 & . & 2 & . & . & 1 & . & 1 & . & . & 3 & 0 & . & . & 1 & . & . & 11 & 0 & . & 2 & . & . & 3 & . & 1 & . & . & 1 \\
\hline Iris pseudacorus & 9 & 0 & 1 & . & 13 & 1 & 28 & 9 & 8 & 3 & 6 & 1 & 1 & . & 8 & 2 & 1 & 2 & . & 4 & 0 & 1 & 4 & 1 & 1 & 2 & 1 & 3 & 5 & 3 & 4 & 1 & . & 4 \\
\hline Lythrum salicaria & . & . & . & 2 & 8 & 1 & 5 & 1 & 5 & 7 & 10 & & 1 & 1 & . & 2 & 3 & 2 & 1 & 3 & 3 & 2 & 1 & 1 & 12 & 2 & 1 & . & 3 & 1 & 2 & 0 & . & 2 \\
\hline Leersia oryzoides & - & . & . & 2 & . & 1 & . & 6 & . & . & 5 & 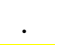 & 1 & . & . & . & 0 & . & . & . & . & . & 8 & 0 & & . & . & . & . & . & . & . & . & . \\
\hline Ranunculus circinatus & 1 & 1 & 11 & . & . & 1 & . & 5 & . & . & . & 9 & 0 & . & . & . & 0 & . & 5 & 2 & 0 & . & . & 0 & 1 & 1 & . & . & 0 & 2 & . & 1 & . & 4 \\
\hline Sium latifolium & & & . & . & . & & . & & . & . & & & & 5 & & - & 0 & 1 & 1 & & 2 & 0 & & & 1 & . & 2 & . & . & . & . & & . & . \\
\hline Nasturtium officinale & 6 & 1 & . & . & 36 & 1 & . & 9 & . & . & 0 & . & 0 & 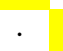 & 8 & . & 1 & 0 & . & 7 & 1 & 0 & 1 & 0 & . & 11 & . & . & 16 & 0 & 3 & 5 & 5 & 5 \\
\hline Juncus effusus & . & . & . & . & . & . & . & . & . & 0 & 3 & . & 0 & 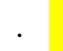 & 23 & 3 & 0 & 0 & . & 2 & . & . & 2 & 0 & & . & . & . & . & . & 0 & . & . & . \\
\hline Sparganium spp. & . & . & . & 9 & . & 3 & . & 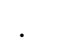 & . & . & 1 & 3 & 1 & . & 8 & . & 1 & 3 & 1 & 4 & 21 & 4 & . & 2 & 16 & . & 3 & . & 1 & . & . & . & . & 2 \\
\hline Mentha aquatica & 3 & . & . & 3 & 20 & 0 & . & 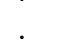 & . & 5 & 2 & 3 & 0 & 4 & . & 1 & 2 & 3 & 29 & 1 & 13 & 1 & 3 & 0 & 6 & 2 & 7 & . & 7 & 0 & 14 & 0 & 4 & 1 \\
\hline Myosotis scorpioides agg. & 10 & . & . & 2 & 10 & 0 & . & 9 & . & 5 & 1 & 3 & 0 & 2 & . & . & 3 & 1 & 14 & 5 & 11 & 2 & 2 & 0 & 2 & 2 & 5 & 18 & 4 & 0 & 2 & 8 & 2 & 3 \\
\hline Alisma spp. & . & . & . & . & . & 0 & . & . & . & . & 1 & 3 & 0 & 2 & . & . & 1 & 0 & 15 & $\cdot$ & 4 & 1 & . & 0 & 5 & 2 & 0 & . & . & . & . & . & . & . \\
\hline Polygonum amphibium & & . & . & . & . & . & . & . & . & . & 4 & 1 & & 2 & . & . & 1 & 1 & 7 & & 2 & 0 & . & . & 3 & 14 & 6 & . & . & $\cdot$ & . & & . & . \\
\hline Potamogeton lucens & . & . & . & . & . & . & . & 2 & . & . & . & . & 2 & . & . & . & 0 & 5 & 4 & . & 1 & 4 & . & 1 & 6 & $\cdot$ & 9 & 10 & 1 & 13 & . & 23 & 1 & 4 \\
\hline $\begin{array}{c}\text { Veronica } \\
\text { anagallis-aquatica }\end{array}$ & 3 & 9 & 3 & 0 & . & 1 & . & 7 & . & 3 & 0 & . & 0 & . & . & . & 1 & 1 & 4 & 9 & 11 & 2 & 3 & 0 & & 8 & 0 & 6 & 12 & 0 & 13 & 13 & 23 & 6 \\
\hline Sagittaria sagittifolia & . & . & . & . & . & . & . & 5 & . & . & . & . & r. & . & . & . & 0 & 1 & . & . & 0 & 4 & . & 1 & $\cdot$ & . & 0 & . & . & 0 & . & 19 & . & 0 \\
\hline Avg. nr. of species & 12 . & & & 6.8 & 19.6 & 65.3 & 13.7 & 712.5 & 512.9 & 98.2 & 8.3 & 7.3 & 4.5 & 7.8 & 4.3 & & 6.5 & 8.8 & 14.0 & 07.8 & 14.6 & & 11.8 & 4.2 & & 69.3 & & 56.7 & 8.2 & 8.8 & 9.6 & 11.5 & & 10.7 \\
\hline
\end{tabular}




\section{References}

1. Ward, J.V. The Four-Dimensional Nature of Lotic Ecosystems. J. N. Am. Benthol. Soc. 1989, 8, 2-8. [CrossRef]

2. Settele, J.; Scholes, R.; Betts, R.A.; Bunn, S.; Leadley, P.; Nepstad, D.; Overpeck, J.T.; Angel Taboada, M.; Adrian, R.; Allen, C.; et al. 2014: Terrestrial and inland water systems. In Climate Change 2014: Impacts, Adaptation, and Vulnerability: Part A: Global and Sectoral Aspects. Contribution of Working Group II to the Fifth Assessment Report of the Intergovernmental Panel on Climate Change; Cambridge University Press: Cambridge, UK, 2014; pp. 1-32.

3. Stanford, J.A. Rivers in the landscape: Introduction to the special issue on riparian and groundwater ecology. Freshw. Biol. 1998, 40, 402-406. [CrossRef]

4. Petts, G.E. Rivers: Dynamic components of catchment ecosystems. In The River's Handbook: Hydrological and Ecological Principles; Calow, P., Petts, G.E., Eds.; Blackwell Science: Oxford, UK, 1994; pp. 3-22.

5. Boulton, A.J.; Brock, M.A. Australian Freshwater Ecology: Processes and Management; Gleneagles Publishing: Adelaide, Australia, 1999; p. 118.

6. Baattrup-Pedersen, A.; Larsen, S.E.; Riis, T. Long-term effects of stream management on plant communities in two Danish lowland streams. Hydrobiology 2002, 481, 33-45. [CrossRef]

7. Kuhar, U.; Gregorc, T.; Renčelj, M.; Šraj-Kržič, N.; Gaberščik, A. Distribution of macrophytes and condition of the physical environment of streams flowing through agricultural landscape in north-eastern Slovenia. Limnologica 2007, 37, 146-154. [CrossRef]

8. Kuhar, U.; Germ, M.; Gaberščik, A. Macrophytes of watercourses in the Slovenian Danube Basin. In Macrophytes of the River Danube Basin; Janauer, G.A., Gaberščik, A., Květ, J., Germ, M., Exler, N., Eds.; Academia: Praha, Czech Republic, 2018 ; pp. 234-251.

9. Petersen, R.C. The RCE: A Riparian, Channel, and Environmental Inventory for small streams in the agricultural landscape. Freshw. Biol. 1992, 27, 295-306. [CrossRef]

10. Szoszkiewicz, K.; Ciecierska, H.; Kolada, A.; Schneider, S.C.; Szwabinska, M.; Ruszczynska, J. Parameters structuring macrophyte communities in rivers and lakes-results from a case study in North-Central Poland. Knowl. Manag. Aquat. Ecosyst. 2014, 415, 8. [CrossRef]

11. Kuhar, U.; Germ, M.; Gaberščik, A.; Urbanič, G. Development of a River Macrophyte Index (RMI) for assessing river ecological status. Limnologica 2011, 41, 235-243. [CrossRef]

12. Haury, J. Patterns of macrophyte distribution within a Breton brook compared with other study scales. Landsc. Urban Plan. 1995, 31, 349-361. [CrossRef]

13. Haslam, S. The evaluation of river pollution using vegetation in the Maltese islands. Fresenius Environ. Bull. $2000,9,347-351$.

14. Verschoren, V.; Schoelynck, J.; Cox, T.; Schoutens, K.; Temmerman, S.; Meire, P. Opposing effects of aquatic vegetation on hydraulic functioning and transport of dissolved and organic particulate matter in a lowland river: A field experiment. Ecol. Eng. 2017, 105, 221-230. [CrossRef]

15. Bakker, E.; Van Donk, E.; Declerck, S.; Helmsing, N.; Hidding, B.; Nolet, B. Effect of macrophyte community composition and nutrient enrichment on plant biomass and algal blooms. Basic Appl. Ecol. 2010, 11, 432-439. [CrossRef]

16. Vestergaard, O.; Sand-Jensen, K. Alkalinity and trophic state regulate aquatic plant distribution in Danish lakes. Aquat. Bot. 2000, 67, 85-107. [CrossRef]

17. Haslam, S.M. River Plants: The Macrophytic Vegetation of Watercourses; Cardigan, Forrest Text: Ceredigion, UK, 2006 ; p. 450.

18. Franklin, P.; Dunbar, M.; Whitehead, P. Flow controls on lowland river macrophytes: A review. Sci. Total. Environ. 2008, 400, 369-378. [CrossRef]

19. Chambers, P.A.; Prepas, E.E.; Hamilton, H.R.; Bothwell, M.L. Current Velocity and Its Effect on Aquatic Macrophytes in Flowing Waters. Ecol. Appl. 1991, 1, 249-257. [CrossRef]

20. Dodds, W.K.; Biggs, B.J.F. Water Velocity Attenuation by Stream Periphyton and Macrophytes in Relation to Growth Form and Architecture. J. North Am. Benthol. Soc. 2002, 21, 2-15. [CrossRef]

21. Biggs, B.J.F. Hydraulic habitat of plants in streams. Regul. Rivers Res. Manag. 1996, 12, 131-144. [CrossRef]

22. Riis, T.; Biggs, B.J.F. Hydrologic and hydraulic control of macrophyte establishment and performance in streams. Limnol. Oceanogr. 2003, 48, 1488-1497. [CrossRef]

23. Riis, T.; Suren, A.M.; Clausen, B.; Sand-Jensen, K. Vegetation and flow regime in lowland streams. Freshw. Biol. 2008, 53, 1531-1543. [CrossRef]

24. Fox, A.M. Macrophytes. In The River's Handbook: Hydrological and Ecological Principles; Calow, P., Petts, G.E., Eds.; Blackwell Science: Oxford, UK, 1992; pp. 216-233.

25. Murphy, K.J.; Rørslett, B.; Springuel, I. Strategy analysis of submerged lake macrophyte communities: An international example. Aquat. Bot. 1990, 36, 303-323. [CrossRef]

26. Riis, T.; Tank, J.L.; Reisinger, A.J.; Aubenau, A.; Roche, K.R.; Levi, P.S.; Baattrup-Pedersen, A.; Alnoee, A.B.; Bolster, D. Riverine macrophytes control seasonal nutrient uptake via both physical and biological pathways. Freshw. Biol. 2019, 65, 178-192. [CrossRef]

27. Baattrup-Pedersen, A.; Larsen, S.E.; Riis, T. Composition and richness of macrophyte communities in small Danish streamsinfluence of environmental factors and weed cutting. Hydrobiologia 2003, 495, 171-179. [CrossRef] 
28. Baattrup-Pedersen, A.; Riis, T. Macrophyte diversity and composition in relation to substratum characteristics in regulated and unregulated Danish streams. Freshw. Biol. 1999, 42, 375-385. [CrossRef]

29. Chambers, P.A.; Lacoul, P.; Murphy, K.J.; Thomaz, S.M. Global diversity of aquatic macrophytes in freshwater. In Freshwater Animal Diversity Assessment; Springer: Berlin, Germany, 2008; pp. 9-26.

30. Pip, E. Water temperature and freshwater macrophyte distribution. Aquat. Bot. 1989, 34, 367-373. [CrossRef]

31. Léonard, R.; Legendre, P.; Jean, M.; Bouchard, A. Using the landscape morphometric context to resolve spatial patterns of submerged macrophyte communities in a fluvial lake. Landsc. Ecol. 2007, 23, 91-105. [CrossRef]

32. Gacia, E.; Ballesteros, E.; Camarero, L.; Delgado, O.; Palau, A.; Riera, J.L.; Catalan, J. Macrophytes from lakes in the eastern Pyrenees: Community composition and ordination in relation to environmental factors. Freshw. Biol. 1994, 32, 73-81. [CrossRef]

33. Manzo, L.; Grech, M.; Epele, L.; Kutschker, A.; Miserendino, M. Macrophyte regional patterns, metrics assessment and ecological integrity of isolated ponds at Austral Patagonia (Argentina). Sci. Total. Environ. 2020, 727, 138617. [CrossRef] [PubMed]

34. Wraber, M. Pflanzengeographische Stellung und Gliedernung Sloweniens. Vegetatio 1969, 17, 176-199. [CrossRef]

35. Sket, B. Oblikuje se današnje živalstvo. In Fauna of Slovenia; Sket, B., Gogala, M., Kuštor, V., Eds.; Tehniška založba Slovenije: Ljubljana, Slovenia, 2003; pp. 41-55.

36. Illies, J. Limnofauna Europaea: Eine Zusammenstellung Aller Die Europäischen Binnengewässer bewohnenden Mehrzelligen Tierarten Mit Angaben Über Ihre Verbreitung Und Ökologie; Fischer: Stuttgart, Germany, 1978.

37. Mršić, N. Biotic Diversity in Slovenia: Slovenia-the "Hot Spot" of Europe; Ministrstvo za Okolje in Prostor, Uprava RS za Varstvo Narave: Ljubljana, Slovenia, 1997; p. 129.

38. Urbanic, G. Redelineation of European inland water ecoregions in Slovenia. Rev. Hydrobiol. 2008, 1, 17-25.

39. Šraj-Kržič, N.; Germ, M.; Urbanc-Berčič, O.; Kuhar, U.; Janauer, G.A.; Gaberščik, A. The quality of the aquatic environment and macrophytes of karstic watercourses. Plant Ecol. 2007, 192, 107-118. [CrossRef]

40. Hawes, I.; Riis, T.; Sutherland, D.; Flanagan, M. Physical Constraints to Aquatic Plant Growth in New Zealand Lakes. J. Publ. Title 2003, 41, 44-52.

41. Van Geest, G.J.; Coops, H.; Roijackers, R.M.M.; Buijse, A.D.; Scheffer, M. Succession of aquatic vegetation driven by reduced water-level fluctuations in floodplain lakes. J. Appl. Ecol. 2005, 42, 251-260. [CrossRef]

42. Alahuhta, J.; Lindholm, M.; Baastrup-Spohr, L.; García-Girón, J.; Toivanen, M.; Heino, J.; Murphy, K. Macroecology of macrophytes in the freshwater realm: Patterns, mechanisms and implications. Aquat. Bot. 2021, 168, 103325. [CrossRef]

43. Jenačković, D.D.; Zlatković, I.D.; Lakušić, D.V.; Ranđelović, V.N. The assessment of seasonal variability in emergent macrophyte communities. Biologia 2016, 71, 287-297. [CrossRef]

44. Landucci, F.; Řezníčková, M.; Šumberová, K.; Chytrý, M.; Aunina, L.; Biţă-Nicolae, C.; Bobrov, A.; Borsukevych, L.; Brisse, H.; ČARNI, A.; et al. WetVegEurope: A database of aquatic and wetland vegetation of Europe. Phytocoenologia 2015, 45, 187-194. [CrossRef]

45. Hrvatin, M.; Tičar, J.; Zorn, M. Rocks and Tectonic Structure of Slovenia. In The Geography of Slovenia; Perko, D., Ed.; Springer Nature Switzerland AG: Cham, Switzerland, 2020; pp. 23-34.

46. Komac, B.; Pavšek, M.; Topole, M. Climate and Weather of Slovenia. In The Geography of Slovenia; Perko, D., Ed.; Springer Nature Switzerland AG: Cham, Switzerland, 2020; pp. 71-89.

47. Kolbezen, M.; Pristov, J.; Bat, M.; Klemenc, B.; Hrček, D. Surface Streams and Water Balance of Slovenia; Ministrstvo za Okolje in Prostor: Ljubljana, Slovenia, 1998; p. 98.

48. Janauer, G.; Exler, N.; Anačkov, G.; Barta, V.; Berczik, Á.; Boža, P.; Dinka, M.; Georgiev, V.; Germ, M.; Holcar, M.; et al. Distribution of the Macrophyte Communities in the Danube Reflects River Serial Discontinuity. Water 2021, 13, 918. [CrossRef]

49. Köhler, A.; Janauer, G.A. Zur Methodik der Untersuchung von aquatischen Makrophyten in Fließgewässern. Handbuch Angewandte Limnologie: Grundlagen-Gewässerbelastung-Restaurierung-Aquatische Ökotoxikologie-Bewertung-Gewässerschutz 2004, 8, 1-22. [CrossRef]

50. Schneider, S.; Melzer, A. The Trophic Index of Macrophytes (TIM)—A New Tool for Indicating the Trophic State of Running Waters. Int. Rev. Hydrobiol. 2003, 88, 49-67. [CrossRef]

51. Janauer, G.A.; Gaberscik, A.; Kvet, J.; Germ, M.; Exler, N. Macrophytes of the River Danube Basin; Academia: Praha, Czech Republic, 2018; p. 408.

52. Kurtto, A.; Sennikov, A.; Lampinen, R. Atlas Florae Europaeae (AFE)—Distribution of Vascular Plants in Europe; The Committee for Mapping the Flora of Europeand Societas Biologica Fennica Vanamo: Helsinki, Finland, 2013; Available online: https: / / www.luomus.fi/en/atlas-florae-europaeae-afe-distribution-vascular-plants-europe (accessed on 9 February 2021).

53. Schaumburg, J.; Schranz, C.; Foerster, J.; Gutowski, A.; Hofmann, G.; Meilinger, P.; Schneider, S.; Schmedtje, U. Ecological classification of macrophytes and phytobenthos for rivers in Germany according to the water framework directive. Limnologica 2004, 34, 283-301. [CrossRef]

54. Braun-Blanquet, J. Pflanzensoziologie, Grundzüge der Vegetationskunde, 3rd ed.; Springer: Berlin, Germany, $1964 ;$ p. 631.

55. Lukács, B.A.; Tóthmérész, B.; Borics, G.; Várbíró, G.; Juhász, P.; Kiss, B.; Müller, Z.; G-Tóth, L.; Erős, T. Macrophyte diversity of lakes in the Pannon Ecoregion (Hungary). Limnologica 2015, 53, 74-83. [CrossRef]

56. Pall, K.; Gecheva, G.; Soaru-Minea, A.; Lukacs, B.S.P. Intercalibration of the National Classifications of Ecological Status for Eastern Continental Lakes; Publications Office of the European Union: Rue Mercier, Luxembourg, 2018; p. 81. 
57. Germ, M.; Gaberščik, A.; Urbanc-Berčič, O. The wider environmental assessment of river ecosystems. Acta. Biol. Slov. 2000, 43, 13-19.

58. Janauer, G.A.; Exler, N.; Schmidt-Mumm, U. The harmonised method for the macrophyte and habitat survey in the MIDCCproject: River Danube, floodplain waters and tributaries. In Macrophytes of the River Danube Basin; Janauer, G.A., Gaberščik, A., Květ, J., Germ, M., Exler, N., Eds.; Academia: Praha, Czech Republic, 2018; pp. 14-34. ISBN 978-80-200-2743-6.

59. QGIS. Welcome to the QGIS project! Available online: http:/ / www.qgis.org/ (accessed on 25 September 2020).

60. Hammer, Ø.; Harper, D.A.T.; Ryan, P.D. PAST: Paleontological statistics software package for education and data analysis. Palaeontol. Electron. 2001, 4, 1-9.

61. Murtagh, F.; Legendre, P. Ward's Hierarchical Agglomerative Clustering Method: Which Algorithms Implement Ward's Criterion? J. Classif. 2014, 31, 274-295. [CrossRef]

62. Zelnik, I. Vegetation of the Meadows from the Order Molinietalia W. Koch 1926 and Contact Sites in Slovenia. Ph.D. Thesis, University of Ljubljana, Ljubljana, Slovenia, 2005.

63. Hrivnák, R.; Bubíková, K.; Ot'ahel'ová, H.; Šumberová, K. Formalised classification of aquatic vegetation in Slovakia. Phytocoenologia 2019, 49, 107-133. [CrossRef]

64. Landucci, F.; Tichý, L.; Šumberová, K.; Chytrý, M. Formalized classification of species-poor vegetation: A proposal of a consistent protocol for aquatic vegetation. J. Veg. Sci. 2015, 26, 791-803. [CrossRef]

65. Šumberová, K. Vegetation of free floating aquatic plants (Lemnetea). In Vegetation of the Czech Republic. 3, Aquatic and Wetland Vegetation; Chytrý, M., Ed.; Academia: Praha, Czech Republic, 2011; pp. 43-99.

66. Šumberová, K. Vegetation of aquatic plants rooted in the bottom (Potametea). In Vegetation of the Czech Republic. 3, Aquatic and Wetland Vegetation; Chytrý, M., Ed.; Academia: Praha, Czech Republic, 2011; pp. 100-247.

67. Šumberová, K.; Lososová, Z. Vegetation of annual nitrophilous wetland herbs (Bidentetea tripartitae). In Vegetation of the Czech Republic. 3, Aquatic and Wetland Vegetation; Chytrý, M., Ed.; Academia: Praha, Czech Republic, 2011; pp. $347-384$.

68. Šumberová, K.; Hájková, P.; Chytrý, M.; Hroudová, Z.; Sádlo, J.; Hájek, M.; Hrivnák, R.; Navrátilová, J.; Hanáková, P.; Ekrt, L.; et al. Marsh vegetation (Phragmito-Magno-Caricetea). In Vegetation of the Czech Republic. 3, Aquatic and Wetland Vegetation; Chytrý, M., Ed.; Academia: Praha, Czech Republic, 2011; pp. 385-579.

69. Zaliberová, M.; Škodová, I. Flood-meadows. In Plant Communities of Slovakia. 5. Grassland Vegetation; Hegedüšová, K., Škodová, I., Eds.; Veda: Bratislava, Slovakia, 2014.

70. Landucci, F.; Šumberová, K.; Tichý, L.; Hennekens, S.; Aunina, L.; Biță-Nicolae, C.; Borsukevych, L.; Bobrov, A.; Čarni, A.; De Bie, E.; et al. Classification of the European marsh vegetation (Phragmito-Magnocaricetea) to the association level. Appl. Veg. Sci. 2020, 23, 297-316. [CrossRef]

71. Mucina, L.; Bültmann, H.; Dierßen, K.; Theurillat, J.; Raus, T.; Čarni, A.; Šumberová, K.; Willner, W.; Dengler, J.; García, R.G.; et al. Vegetation of Europe: Hierarchical floristic classification system of vascular plant, bryophyte, lichen, and algal communities. Appl. Veg. Sci. 2016, 19, 3-264. [CrossRef]

72. Ter Braak, C.J.F.; Verdonschot, P.F.M. Canonical correspondence analysis and related multivariate methods in aquatic ecology. Aquat. Sci. 1995, 57, 255-289. [CrossRef]

73. Hudon, C.; Gagnon, P.; Jean, M. Hydrological factors controlling the spread of common reed (Phragmites australis) in theSt. Lawrence River (Québec, Canada). Écoscience 2005, 12, 347-357. [CrossRef]

74. Ter Braak, C.J.; Smilauer, P. CANOCO Reference Manual and CanoDraw for Windows User's Guide: Software for Canonical Community Ordination, version 4.5; Research Output of Wageningen University and Research Staff: Ithaca, NY, USA, 2002.

75. Furnas, E.R. Available online: http:/ / www.microcomputerpower.com/ (accessed on 2 March 2021).

76. Fernández-Aláez, M.; García-Criado, F.; García-Girón, J.; Santiago, F.; Fernández-Aláez, C. Environmental heterogeneity drives macrophyte beta diversity patterns in permanent and temporary ponds in an agricultural landscape. Aquat. Sci. 2020, 82, 1-12. [CrossRef]

77. Murphy, K.; Efremov, A.; Davidson, T.A.; Molina-Navarro, E.; Fidanza, K.; Betiol, T.C.C.; Chambers, P.; Grimaldo, J.T.; Martins, S.V.; Springuel, I.; et al. World distribution, diversity and endemism of aquatic macrophytes. Aquat. Bot. 2019, 158, 103127. [CrossRef]

78. Maberly, S.C.; Haslam, S.M. River Plants of Western Europe: The Macrophytic Vegetation of the Watercourses of the European Economic Community. J. Ecol. 1988, 76, 1248. [CrossRef]

79. Preston, C. Pondweeds of Great Britain and Ireland; Botanical Society of the British Isles: London, UK, $1995 ;$ p. 352.

80. Brainard, A.S.; Luzadis, V.A.; Schulz, K.L. Drivers of species richness, biomass, and dominance of invasive macrophytes in temperate lakes. Biol. Invasions 2021, 23, 1069-1085. [CrossRef]

81. Kuhar, U.; Germ, M.; Gaberščik, A. Habitat characteristics of an alien species Elodea canadensis in Slovenian watercourses. Hydrobiologia 2010, 656, 205-212. [CrossRef]

82. O'Hare, M.T.; Baattrup-Pedersen, A.; Nijboer, R.; Szoszkiewicz, K.; Ferreira, T. Macrophyte communities of European streams with altered physical habitat. Hydrobiologia 2006, 566, 197-210. [CrossRef]

83. Janauer, G.; Dokulil, M. Macrophytes and Algae in Running Waters. In Biological Monitoring of Rivers: Applications and Perspectives; John, W., Ed.; Sons Ltd.: Chichester, UK, 2006; pp. 89-109.

84. Li, G.; Hu, S.; Hou, H.; Kimura, S. Heterophylly: Phenotypic Plasticity of Leaf Shape in Aquatic and Amphibious Plants. Plants 2019, 8, 420. [CrossRef] 
85. Boulton, A.J.; Brock, M.A.; Robson, B.J.; Ryder, D.S.; Chambers, J.M.; Davis, J.A. Australian Freshwater Ecology: Processes and Management; Wiley-Blackwell: Hoboken, NJ, USA, 2014; p. 386.

86. Nilsen, E.T.; Orcutt, D.M. Water limitation. In The Physiology of Plants under Stress. Abiotic Factors; John Wiley and Sons: New York, NY, USA, 1996; pp. 322-361.

87. Brink, F.V.D.; Van Der Velde, G.; Bosman, W.; Coops, H. Effects of substrate parameters on growth responses of eight helophyte species in relation to flooding. Aquat. Bot. 1995, 50, 79-97. [CrossRef]

88. Grimaldo, J.T.; O’Hare, M.T.; Kennedy, M.P.; Davidson, T.A.; Bonilla-Barbosa, J.; Santamaría-Araúz, B.; Gettys, L.; Martins, S.V.; Thomaz, S.M.; Murphy, K.J. Environmental drivers of freshwater macrophyte diversity and community composition in calcareous warm-water rivers of America and Africa. Freshw. Biol. 2017, 62, 1511-1527. [CrossRef]

89. Vannote, R.L.; Minshall, G.W.; Cummins, K.W.; Sedell, J.R.; Cushing, C.E. The River Continuum Concept. Can. J. Fish. Aquat. Sci. 1980, 37, 130-137. [CrossRef]

90. Kennedy, M.P.; Lang, P.; Grimaldo, J.T.; Martins, S.V.; Bruce, A.; Hastie, A.; Lowe, S.; Ali, M.M.; Sichingabula, H.; Dallas, H.; et al. Environmental drivers of aquatic macrophyte communities in southern tropical African rivers: Zambia as a case study. Aquat. Bot. 2015, 124, 19-28. [CrossRef]

91. Alahuhta, J.; Lindholm, M.; Bove, C.P.; Chappuis, E.; Clayton, J.; De Winton, M.; Feldmann, T.; Ecke, F.; Gacia, E.; Grillas, P.; et al. Global patterns in the metacommunity structuring of lake macrophytes: Regional variations and driving factors. Oecologia $\mathbf{2 0 1 8}$ 188, 1167-1182. [CrossRef]

92. Grinberga, L. Environmental factors influencing the vegetation in middle-sized streams in Latvia. Ann. Bot. 2011, 1, 37-44. [CrossRef]

93. Madsen, J.D.; Chambers, P.A.; James, W.F.; Koch, E.W.; Westlake, D.F. The interaction between water movement, sediment dynamics and submersed macrophytes. Hydrobiologia 2001, 444, 71-84. [CrossRef]

94. Connell, J.H. Diversity in Tropical Rain Forests and Coral Reefs. Science 1978, 199, 1302-1310. [CrossRef]

95. Mjelde, M.; Faafeng, B. Ceratophyllum demersum hampers phytoplankton development in some small Norwegian lakes over a wide range of phosphorus concentrations and geographical latitude. Freshw. Biol. 1997, 37, 355-365. [CrossRef]

96. Hutchinson, G.E. The chemical ecology of three species of myriophyllum (Angiospermae, Haloragaceae) 1,2. Limnol. Oceanogr. 1970, 15, 1-5. [CrossRef]

97. Grace, B.J.; Wetzel, R.G. The Production Biology of Eurasian Watermilfoil (Myriophyllum spicatum L.): A Review. J. Aquat. Plant Manag. 1978, 16, 1-11.

98. Van Wijk, R. Ecological studies on Potamogeton pectinatus L. I. General characteristics, biomass production and life cycles under field conditions. Aquat. Bot. 1988, 31, 211-258. [CrossRef]

99. Germ, M.; Kuhar, U.; Gaberščik, A. Abundance and Diversity of Taxa Within the Genus Potamogeton in Slovenian Watercourses. In Natural and Constructed Wetlands; Springer International Publishing: Cham, Switzerland, 2016; pp. $283-291$.

100. Dolinar, N.; Regvar, M.; Abram, D.; Gaberščik, A. Water-level fluctuations as a driver of Phragmites australis primary productivity, litter decomposition, and fungal root colonisation in an intermittent wetland. Hydrobiologia 2015, 774, 69-80. [CrossRef]

101. Gaberščik, A.; Grašič, M.; Abram, D.; Zelnik, I. Water Level Fluctuations and Air Temperatures Affect Common Reed Habitus and Productivity in an Intermittent Wetland Ecosystem. Water 2020, 12, 2806. [CrossRef]

102. Martinčič, A. Pteridophytes and Spermatophytes. In Vanishing Lake-Monography on lake Cerknica (Slovenian with English Summary); Gaberščik, A., Ed.; Društvo ekologov Slovenije: Ljubljana, Slovenia, 2002; pp. 76-80.

103. Jenačković, D.D.; Zlatković, I.D.; Lakušić, D.V.; Ranđelović, V.N. Macrophytes as bioindicators of the physicochemical characteristics of wetlands in lowland and mountain regions of the central Balkan Peninsula. Aquat. Bot. 2016, 134, 1-9. [CrossRef]

104. Clevering, A.O.; Brix, H.; Lukavská, J. Geographic variation in growth responses in Phragmites australis. Aquat. Bot. 2001, 69, 89-108. [CrossRef]

105. Píšová, S.; Fér, T. Intraspecific differentiation of Sparganium erectum in the Czech Republic. PRESLIA 2020, 92. [CrossRef]

106. Landucci, F.; Republic, C.; Gigante, D.; Venanzoni, R.; Chytrý, M. Wetland vegetation of the class Phragmito-Magno-Caricetea in centralItaly. Phytocoenologia 2013, 43, 67-102. [CrossRef]

107. Misson, G.; Macor, A.; Boscutti, F.; Casolo, V. Ecological characterisation of Hippuris vulgaris populations growing in spring Water Rivers. Phyton (Horn) 2016, 56, 209-224. [CrossRef] 